\title{
Article \\ Environmental, Economic and Social Impact Assessment: Study of Bridges in China's Five Major Economic Regions
}

\author{
ZhiWu Zhou*(D), Julián Alcalá and Víctor Yepes
}

check for updates

Citation: Zhou, Z.; Alcalá, J.; Yepes, V. Environmental, Economic and Social Impact Assessment: Study of Bridges in China's Five Major Economic Regions. Int. J. Environ. Res. Public Health 2021, 18, 122. https://doi.org/ 10.3390/ijerph18010122

Received: 26 November 2020 Accepted: 22 December 2020 Published: 26 December 2020

Publisher's Note: MDPI stays neutral with regard to jurisdictional clai$\mathrm{ms}$ in published maps and institutional affiliations.

Copyright: (C) 2020 by the authors. Licensee MDPI, Basel, Switzerland. This article is an open access article distributed under the terms and conditions of the Creative Commons Attribution (CC BY) license (https:// creativecommons.org/licenses/by/ $4.0 /)$.
Institute of Concrete Science and Technology (ICITECH), Universitat Politècnica de València, 46022 València, Spain; jualgon@cst.upv.es (J.A.); vyepesp@cst.upv.es (V.Y.)

* Correspondence: zhizh2@doctor.upv.es; Tel.: +34-96-387-9563

\begin{abstract}
The construction industry of all countries in the world is facing the issue of sustainable development. How to make effective and accurate decision-making on the three pillars (Environment; Economy; Social influence) is the key factor. This manuscript is based on an accurate evaluation framework and theoretical modelling. Through a comprehensive evaluation of six cable-stayed highway bridges in the entire life cycle of five provinces in China (from cradle to grave), the research shows that life cycle impact assessment (LCIA), life cycle cost assessment (LCCA), and social impact life assessment (SILA) are under the influence of multi-factor change decisions. The manuscript focused on the analysis of the natural environment over 100 years, material replacement, waste recycling, traffic density, casualty costs, community benefits and other key factors. Based on the analysis data, the close connection between high pollution levels and high cost in the maintenance stage was deeply promoted, an innovative comprehensive evaluation discrete mathematical decisionmaking model was established, and a reasonable interval between gross domestic product (GDP) and sustainable development was determined.
\end{abstract}

Keywords: sustainable development; LCIA; LCCA; SILA; cable-stayed bridge; GDP

\section{Introduction}

The most common greenhouse gases in the Earth's atmosphere include water vapour $\left(\mathrm{H}_{2} \mathrm{O}\right)$, carbon dioxide $\left(\mathrm{CO}_{2}\right)$, methane $\left(\mathrm{CH}_{4}\right)$, nitrous oxide $\left(\mathrm{N}_{2} \mathrm{O}\right)$, ozone $\left(\mathrm{O}_{3}\right)$ and chlorofluorocarbons (CFC). The concentration of carbon dioxide in the atmosphere has a dominant influence on global warming [1,2]. According to predictions by the United Nations, the world's population will reach 9.8 billion in 2050 [3]. Population shifts will result in a massive consumption of resources and a rapid growth of energy requirements [4]. This makes the sustainable development of the construction industry, which accounts for $44 \%$ of all energy consumption, become more urgent $[5,6]$. What is the key to sustainable development? It is to reduce environmental, economic and social impacts [7]. Thus, the scope of research is expanded to the economic and social aspects, and the close correlation between producers and consumers is increased [8].

To avoid the serious consequences brought about by climate change, efforts should be made to substantially reduce the emission of greenhouse gases. Hansen et al. revealed that the concentration of carbon dioxide in the atmosphere must be less than 350 parts per million (ppm); otherwise, climate change will get worse [9]. The analysis of the latest global atmospheric observations by the World Meteorological Organisation shows that the global mean surface mole fractions of $\mathrm{CO}_{2}, \mathrm{CH}_{4}$, and $\mathrm{N}_{2} \mathrm{O}$ reached new highs in 2015, i.e., $400.0 \pm 0.1 \mathrm{ppm}, 1845 \pm 2$ parts per billion (ppb), and $328.0 \pm 0.1 \mathrm{ppb}$, respectively. These values constitute $144 \%, 256 \%$ and $121 \%$ of the pre-industrial levels (before 1750 ), respectively [10].

Low-carbon energy consumption and the reduction in greenhouse gas emissions from the construction industry are particularly critical [11]. Lin and Liu. cited the $\mathrm{CO}_{2}$ emissions from commercial and residential buildings in China, surveyed by the Index Decomposition 
Analysis (IDA), which concluded that emissions from the construction industry account for $30-50 \%$ of the total emissions [12]. Science researchers all over the world have proposed measures to reduce environmental pollution caused by the construction industry. For the accuracy and systematisms of the research, LCIA was introduced to solve problems facing the construction industry $[13,14]$. Standardised provisions for multiple systemic analysis methods were given in ISO 14040 and ISO 14044 [15].

Table 1 shows a comparative analysis of the latest research results of LCIA, LCCA and SILA.

Table 1. Recent statistics and analysis of some closely related achievements.

\begin{tabular}{|c|c|c|c|c|}
\hline Methods & Description & Characteristic & Limitation & References \\
\hline \multirow{5}{*}{ LCIA } & $\begin{array}{l}\text { Preventive design using } 15 \\
\text { different methods of LCA } \\
\text { concrete bridge deck. }\end{array}$ & $\begin{array}{l}\text { How to reduce } \\
\text { environmental pollution in } \\
\text { the maintenance stage: } \\
\text { Design and evaluation of } \\
15 \text { preventive measures. }\end{array}$ & $\begin{array}{l}\text { The research content is } \\
\text { relatively concentrated, } \\
\text { single, and focuses on } \\
\text { material replacement. }\end{array}$ & [16] \\
\hline & $\begin{array}{l}\text { Use LCIA to evaluate the } \\
\text { rationality of the } \\
\text { bridge design. }\end{array}$ & $\begin{array}{l}\text { Use wooden bridges and } \\
\text { alternative concrete to } \\
\text { analyse the LCA impact of } \\
\text { a cable-stayed bridge. }\end{array}$ & $\begin{array}{l}\text { Ideal research design for the } \\
\text { future. There are currently } \\
\text { no large-span wooden } \\
\text { bridges in operation. There } \\
\text { are assumptions and } \\
\text { uncertainties in the } \\
\text { maintenance assessment of } \\
\text { wooden bridges. }\end{array}$ & [17] \\
\hline & $\begin{array}{c}\text { Apply life cycle } \\
\text { sustainability assessment } \\
\text { to the superstructure of } \\
\text { small span bridges. }\end{array}$ & $\begin{array}{l}\text { The study was conducted } \\
\text { using } 27 \text { bridges, and it } \\
\text { was determined that a } \\
\text { bridge composed of steel } \\
\text { and concrete was the } \\
\text { best indicator. }\end{array}$ & $\begin{array}{l}\text { The LCA study of ordinary } \\
\text { highway bridges, the } \\
\text { conclusion is whether it is } \\
\text { suitable for long-span } \\
\text { special bridges. }\end{array}$ & [18] \\
\hline & $\begin{array}{l}\text { LCA was used to assess the } \\
\text { environmental impact of } \\
\text { the entire } 60 \text {-year life span } \\
\text { of the provincial highway. }\end{array}$ & $\begin{array}{l}\text { The research structure has } \\
\text { a complete range of } \\
\text { tunnels, bridges, roadbeds, } \\
\text { culverts, etc. }\end{array}$ & $\begin{array}{l}\text { The road selection is in a } \\
\text { remote area, and the research } \\
\text { data are not representative. }\end{array}$ & [19] \\
\hline & $\begin{array}{l}\text { Several cases (schools, } \\
\text { hospitals, commercial and } \\
\text { residential buildings) were } \\
\text { quantitatively studied } \\
\text { using LCA. }\end{array}$ & $\begin{array}{l}\text { There are many types of } \\
\text { structures studied, and an } \\
\text { evaluation model is } \\
\text { established to } \\
\text { quantitatively } \\
\text { analyse emissions. }\end{array}$ & $\begin{array}{c}\text { The research conclusions are } \\
\text { poorly comparable, and the } \\
\text { LCA data are } \\
\text { highly uncertain. }\end{array}$ & [20] \\
\hline \multirow{3}{*}{ LCCA } & $\begin{array}{l}\text { The article introduces a } \\
\text { general framework for } \\
\text { evaluating bridge life cycle } \\
\text { performance and cost. }\end{array}$ & $\begin{array}{l}\text { The focus is on analysis, } \\
\text { prediction, optimization } \\
\text { and decision-making } \\
\text { under bridge uncertainty. }\end{array}$ & $\begin{array}{l}\text { All the articles in this article } \\
\text { are cost theory analysis, and } \\
\text { there is no specific bridge } \\
\text { case analysis. }\end{array}$ & [21] \\
\hline & $\begin{array}{c}\text { Research and develop an } \\
\text { LCCA model to evaluate } \\
\text { highway infrastructure } \\
\text { investment. }\end{array}$ & $\begin{array}{l}\text { Contributed to the } \\
\text { systematic and } \\
\text { informatised evaluation } \\
\text { method of highway } \\
\text { infrastructure investment. }\end{array}$ & $\begin{array}{l}\text { Lack of case studies and } \\
\text { model application research. }\end{array}$ & [22] \\
\hline & $\begin{array}{l}\text { The energy consumption } \\
\text { cost of highway pavement } \\
\text { is analysed based on LCCA } \\
\text { and LCA. }\end{array}$ & $\begin{array}{l}\text { Combining LCA and } \\
\text { LCCA to determine the } \\
\text { best pavement frame, road } \\
\text { expansion projects are } \\
\text { more practical. }\end{array}$ & $\begin{array}{l}\text { Case application analysis of } \\
\text { pavement concrete } \\
\text { sustainability, no structural } \\
\text { concrete evaluation. }\end{array}$ & [23] \\
\hline
\end{tabular}


Table 1. Cont.

\begin{tabular}{|c|c|c|c|c|}
\hline Methods & Description & Characteristic & Limitation & References \\
\hline & $\begin{array}{l}\text { Quantify the life cycle } \\
\text { environmental impact of the } \\
\text { structure through } \\
\text { environmental costs. }\end{array}$ & $\begin{array}{l}\text { Calculate the environmental } \\
\text { costs of materials, energy, } \\
\text { transportation and } \\
\text { construction equipment for } \\
\text { the bridge structure. }\end{array}$ & $\begin{array}{l}\text { The main research is the } \\
\text { LCCA influence of the bridge } \\
\text { girder structure. }\end{array}$ & [24] \\
\hline & $\begin{array}{l}\text { The LCC and LCA analysis } \\
\text { of concrete bridges were } \\
\text { discussed, and the } \\
\text { optimization scheme was } \\
\text { proposed. }\end{array}$ & $\begin{array}{c}\text { Economic and } \\
\text { environmental impact } \\
\text { analysis of reinforced } \\
\text { concrete and prestressed } \\
\text { concrete bridges. }\end{array}$ & $\begin{array}{l}\text { The bridge structure is } \\
\text { simply a simply supported } \\
\text { beam bridge across the river. }\end{array}$ & [25] \\
\hline & $\begin{array}{l}\text { Use SLCA to clarify the } \\
\text { assessment (IA) methods } \\
\text { and information covered in } \\
\text { the different impact } \\
\text { guidelines. }\end{array}$ & $\begin{array}{l}\text { Use representational } \\
\text { models to analyse the } \\
\text { difference and connection } \\
\text { between social influence } \\
\text { and social performance. }\end{array}$ & $\begin{array}{c}\text { All are written descriptions, } \\
\text { without modeling and } \\
\text { data analysis. }\end{array}$ & [26-28] \\
\hline & $\begin{array}{l}\text { Use SIA to study and } \\
\text { practice all issues related to } \\
\text { social issues in the entire } \\
\text { project life cycle (before } \\
\text { conception to } \\
\text { after closure). }\end{array}$ & $\begin{array}{l}\text { Analysed the overall social } \\
\text { issues in the process of } \\
\text { community and project } \\
\text { management. Put forward } \\
\text { that the biggest social } \\
\text { problem management in } \\
\text { the project is corruption. }\end{array}$ & $\begin{array}{l}\text { Lack of case application } \\
\text { analysis and discussion. }\end{array}$ & {$[29,30]$} \\
\hline & $\begin{array}{l}\text { SIA is undergoing a } \\
\text { revolutionary force and } \\
\text { revolutionary force } \\
\text { for change. }\end{array}$ & $\begin{array}{l}\text { SIA's unfamiliarity with } \\
\text { social sciences and the } \\
\text { concerns of practitioners' } \\
\text { lack of competence. }\end{array}$ & $\begin{array}{l}\text { Lack of case application } \\
\text { analysis and discussion. }\end{array}$ & {$[31,32]$} \\
\hline & $\begin{array}{c}\text { EIA and SIA have technical } \\
\text { flaws in analysis } \\
\text { and evaluation. }\end{array}$ & $\begin{array}{l}\text { Consider four conceptual } \\
\text { elements in a sociological } \\
\text { context of complexity } \\
\text { and vitality. }\end{array}$ & $\begin{array}{l}\text { Talked about the project } \\
\text { SIA's attention to sensitive } \\
\text { factors and the improvement } \\
\text { of social responsibility. How } \\
\text { to realize the scientific } \\
\text { methodology needs to } \\
\text { be developed. }\end{array}$ & {$[33,34]$} \\
\hline \multirow{4}{*}{ LCIA $\backslash$ LCCA $\backslash$ SILA } & $\begin{array}{l}\text { Evaluate the sustainability } \\
\text { performance of different } \\
\text { concrete and stone walls } \\
\text { used in the building. }\end{array}$ & $\begin{array}{c}\text { Multi-criteria decision } \\
\text { analysis methods are used } \\
\text { to evaluate and prioritise } \\
\text { the alternative walls } \\
\text { generated by LCA, LCC } \\
\text { and S-LCA. }\end{array}$ & $\begin{array}{l}\text { The research is sustainable } \\
\text { and comprehensive, the } \\
\text { evaluation structure is single, } \\
\text { and recycling is } \\
\text { not considered. }\end{array}$ & [35] \\
\hline & $\begin{array}{l}\text { The study analysed the } \\
\text { impact of different mixed } \\
\text { timber building structures } \\
\text { on three different } \\
\text { categories of environment, } \\
\text { economy and society. }\end{array}$ & $\begin{array}{l}\text { The comparison of wood } \\
\text { and concrete in the } \\
\text { building structure has been } \\
\text { analysed to } \\
\text { improve sustainability. }\end{array}$ & $\begin{array}{l}\text { There are few studies on the } \\
\text { three pillars of sustainability. } \\
\text { This article has the same } \\
\text { research route and } \\
\text { different structures. }\end{array}$ & {$[36]$} \\
\hline & $\begin{array}{l}\text { Three box-type concrete } \\
\text { bridges were optimised } \\
\text { and sustainable. }\end{array}$ & $\begin{array}{l}\text { Researchers focus on the } \\
\text { environmental pillar, while } \\
\text { the social pillar has been } \\
\text { slow to develop. }\end{array}$ & $\begin{array}{l}\text { It mainly studies the process } \\
\text { of sustainability assessment } \\
\text { and briefly analyses three } \\
\text { precast concrete bridges. }\end{array}$ & [37] \\
\hline & $\begin{array}{l}\text { Discussed the framework } \\
\text { for assessing the } \\
\text { sustainability of bridges, } \\
\text { including related technical, } \\
\text { economic, environmental } \\
\text { and social issues. }\end{array}$ & $\begin{array}{l}\text { The sustainability of four } \\
\text { versions of the same bridge } \\
\text { was studied, and the local } \\
\text { details of the bridge } \\
\text { were analysed. }\end{array}$ & $\begin{array}{l}\text { There is a lack of sustainable } \\
\text { research on regional and } \\
\text { actual operating bridges. }\end{array}$ & [38] \\
\hline
\end{tabular}


First, this study aims to evaluate the impact of LCIA LCCA SILA (2L 1S) on six bridges in five different regions of China. This study will fill the gap in the research for bridges of similar structure and purpose across regions, provinces, and economic belts in this field. Secondly, the process of $2 \mathrm{~L} \sim 1 \mathrm{~S}$ is digitised and visualised to display the research results more intuitively. Thirdly, this study also considers the mutual influence between $2 \mathrm{~L} \sim 1 \mathrm{~S}$ and the regional economic belts, to obtain the optimal interval and scope of influence.

The main purpose of this research is to analyse and study the comprehensive impact of bridges of the same structure in different regional economic zones on the environment, economy and society (three pillars) throughout their life cycle through software. In addition, discussed the correlation between regional economic development and the three pillars through modelling.

The innovations of the research are as follows: (1) break through the usual sustainability research and only focus on textual descriptions, without accurate modelling data descriptions; (2) the selected research case represents the influence status between the main economic belts in China and has important guiding significance for the future planning of the government and related departments.

The rest of this work will be divided into the following sections: Section 2: Methods; Section 3: Results and Discussion; Section 4: Conclusions.

\section{Methods}

LCIA has become an international standardisation tool for environmental assessment $[39,40]$. Preliminary conditions need to be defined for every study: the functional unit and system boundary of the assessment were the six bridges and the SILAs of the corresponding communities. The assessment was conducted based on the LCIA, covering the whole of the life cycle. LCIA was analysed by using OpenLCA (Life cycle assessment) 1.10.1, LCCA by the budgetary estimate process, and SILA by OpenLCA1.10.3 (OpenLCA development team, Berlin, Germany) [14]. The three tools are relevant and systematic. The databases used in this study included Ecoinvent [41], Bedec [42], and Product Social Impact Life Cycle Assessment (PSILCA) [43]. See Sections 2.1 and 2.2 for detailed modelling.

\subsection{Modeling Analysis}

The construction industry is the most active sector in both developed and developing countries, forming a high global consistency [44]. LCIA was included as a sustainable survey method, because it can systematically assess the environment in all directions and complete the selection of friendly products [45]. ISO has issued a series of 14,040 standards and International Life Cycle Data (ILCD) manuals to promote sustainable development $[15,46]$.

\subsubsection{LCIA}

The studied cases were six representative cable-stayed bridges, including South Tai Hu Lake Bridge (STHB), Shenzhen Bay Bridge (SZBB), New Bridge of Xishuangbanna Tropical Botanical Garden (BGNB), Cable-stayed Bridge of Changjiang West Road, Deyang City (CJWB), Hanjiang Highway Bridge, Xiantao City (XTHB), and Baishan Bridge, Baishan City (BSCB). Five of them adopted a reinforced concrete structure and one adopted a steel structure (the main beam of SZBB is constructed by welding and bolting steel components). All of them have a single tower. The length of the main bridge ranges from 136 to $410 \mathrm{~m}$ and all six bridges are Class I municipal highway bridges. Table 2 shows the detailed data. 
Table 2. Cable-stayed bridge maintenance data statistics table.

\begin{tabular}{|c|c|c|c|}
\hline Check Method & Inspection Cycle & Check Parts & Maintenance Cycle \\
\hline 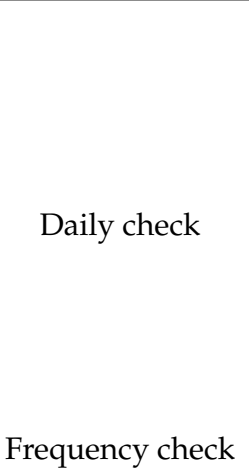 & One time/every month & $\begin{array}{l}\text { Pier foundation, cone slope, side wall of } \\
\text { bridge abutment, pavement of bridge } \\
\text { deck, drainage system, sidewalk, railing, } \\
\text { guardrail, anti-collision wall of bridge } \\
\text { deck, lighting system on bridge, } \\
\text { expansion device, bridge head laying } \\
\text { plate, sign, marking and traffic safety } \\
\text { facilities, bridge installation sensors, } \\
\text { wiring, cables, anchorage protection } \\
\text { inspection, bridge damping device } \\
\text { normal operation, support cleaning, rust } \\
\text { and corrosion prevention. }\end{array}$ & $\begin{array}{l}\text { Maintenance/year, } \\
\text { Overhaul/5 years. }\end{array}$ \\
\hline \multirow{8}{*}{ Regular check } & \multirow{8}{*}{$\begin{array}{l}\text { One time/one to } \\
\text { three years }\end{array}$} & Coating layer of exposed concrete. & $\begin{array}{l}\text { Maintenance/year, } \\
\text { Replacement/5 years. }\end{array}$ \\
\hline & & Bridge deck paving, waterproof layer. & $\begin{array}{l}\text { Maintenance/year, } \\
\text { Overhaul/2 years, } \\
\text { Replacement } / 10 \text { years. }\end{array}$ \\
\hline & & Anti-collision guardrail, expansion joint. & $\begin{array}{l}\text { Maintenance/year, } \\
\text { Overhaul/2-5 years, } \\
\text { Replacement/15 years. }\end{array}$ \\
\hline & & $\begin{array}{l}\text { Cable-stayed bridge cables, slings, tie } \\
\text { rods, external damping devices. }\end{array}$ & $\begin{array}{l}\text { Maintenance/year, } \\
\text { Overhaul/5 years, } \\
\text { Replacement } / 20 \text { years. }\end{array}$ \\
\hline & & $\begin{array}{l}\text { Main beams, steel supports, bridge floor } \\
\text { drainage pipes, bridge floor lighting } \\
\text { facilities. }\end{array}$ & $\begin{array}{l}\text { Maintenance/year, } \\
\text { Overhaul/5 years, } \\
\text { Replacement } / 50 \text { years. }\end{array}$ \\
\hline & & Basin type rubber bearing. & $\begin{array}{l}\text { Maintenance/year, } \\
\text { Overhaul/ } 5 \text { years, } \\
\text { Replacement } / 25 \text { years. }\end{array}$ \\
\hline & & $\begin{array}{l}\text { Damping device between towers } \\
\text { and beams. }\end{array}$ & $\begin{array}{l}\text { Maintenance/year, } \\
\text { Overhaul/5 years, } \\
\text { Replacement } / 30 \text { years. }\end{array}$ \\
\hline & & $\begin{array}{l}\text { Main beams, steel supports, bridge floor } \\
\text { drainage pipes, bridge floor lighting } \\
\text { facilities. }\end{array}$ & $\begin{array}{l}\text { Maintenance/year, } \\
\text { Overhaul/5 years, } \\
\text { Replacement } / 50 \text { years. }\end{array}$ \\
\hline
\end{tabular}

According to ISO standards, and the requirement for the scope of strict assessment and examination of the life cycle of the bridge [47-49], the full life cycle of these six bridges was analysed in five stages: survey and design, material manufacturing, construction and installation, maintenance and operation, and disassembly and recycling. Since the cross section of the main girder of the bridge is variable, the calculation unit was based on 1 cubic meter. In order to achieve the rationality of the data comparison study and analysis, the study length of the six cable-stayed bridges was selected as a uniform $390 \mathrm{~m}$ to input relevant data (390 $\mathrm{m}$ including the main bridge and some auxiliary bridges).

Seven key impact categories, including energy use, ecotoxicity, acidification, eutrophication, climate change, particulate matter formation and ozone depletion, were determined through the comparative analysis of the oxidation separation of fossil materials and the European Union Product Environmental Footprint (EUPEF) [50-52]. Five of these seven categories were selected as the important goals of bridges' LCIA: global warming potential (GWP), acidification potential (AP), free-water eutrophication potential (FEP), particulate matter formation potential (PMFP), including fumes and dust, and waste potential (WP). 
The assessment and modelling method of LCIA has a midpoint and endpoint. Huijbregts et al. made a clear distinction and explanation in their reports ReCiPe 2008 and 2016 LCIA [53,54]. By comparing the advantages and disadvantages of the two modelling approaches [55], it was found that the midpoint modelling is more appropriate for stages, while the end-point modelling is more appropriate for intervals.

Major modelling formulas of LCIS:

Environmental impact contribution of transport vehicle:

$$
\begin{gathered}
\mathrm{E}_{\mathrm{m}}=\sum_{\mathrm{i}}^{\mathrm{j}}\left\{\mathrm{K}_{\mathrm{im}} \times\left[\sum_{\mathrm{i}}^{\mathrm{j}}\left(\mathrm{K}_{\mathrm{i}}+\mathrm{K}_{2}+\cdots \cdots+\mathrm{K}_{\mathrm{j}}\right)\right] \times \mathrm{M} \times(1+\alpha) \times \mathrm{V}_{\mathrm{m}} \times \lambda_{\mu}+\cdots \cdots\right. \\
\left.+\mathrm{K}_{\mathrm{jm}} \times\left[\sum_{\mathrm{i}}^{\mathrm{j}}\left(\mathrm{K}_{\mathrm{i}}+\mathrm{K}_{2}+\cdots \cdots+\mathrm{K}_{\mathrm{j}}\right)\right] \times \mathrm{M} \times(1+\beta) \times \mathrm{V}_{\mathrm{m}} \times \lambda_{\mu}\right\}
\end{gathered}
$$

where $\mathrm{E}_{\mathrm{m}}=$ Environmental impact contribution of transport vehicle $(\mathrm{kg}) ; \mathrm{K}_{\mathrm{im}}, \mathrm{K}_{\mathrm{jm}}=$ Fuel consumption of vehicles $i, j(L / 100 \mathrm{~km}) ; V_{m}=$ Quantity of surveying vehicles $i, j ; \alpha, \beta=$ Engine fuel loss of different types of vehicles (\%); and $\lambda_{\mu}=$ Physical and chemical environmental emission coefficient of fuel $\mu(\mathrm{kg} / \mathrm{kg})[56]$.

Environmental impact contribution of mechanical equipment:

$$
\mathrm{M}_{\mathrm{m}}=\sum_{\mathrm{i}}^{\mathrm{j}}\left\{\left[\mathrm{G}_{\mathrm{im}} \times(1+\alpha) \times \mathrm{T}_{\mathrm{im}} \times\left(\lambda_{\mu} \oplus \lambda_{\nu}\right)\right]+\cdots \cdots+\left[\mathrm{G}_{\mathrm{jm}} \times(1+\alpha) \times \mathrm{T}_{\mathrm{jm}} \times\left(\lambda_{\mu} \oplus \lambda_{v}\right)\right]\right\}
$$

where $\mathrm{M}_{\mathrm{m}}=$ Environmental impact contribution of mechanical equipment $(\mathrm{kg})$; $\mathrm{G}_{\mathrm{im}}, \mathrm{G}_{\mathrm{jm}}=$ Fuel consumption and power consumption of equipment i j $(\mathrm{kg} / \mathrm{h}, \mathrm{kWh})$; $\mathrm{T}_{\mathrm{im}}=$ Normal working hour of mechanical equipment (h); $\oplus=$ Logic "Or"; and $\lambda_{v}=$ Physical and chemical environmental emission coefficient of electric energy $v(\mathrm{~kg} / \mathrm{kg})$.

Environmental impact contribution of personnel:

$$
\mathrm{P}_{\mathrm{m}}=\mathrm{W}_{\mathrm{m}} \times \lambda_{\mathrm{p}} \times \mathrm{T}_{\mathrm{p}}
$$

where $\mathrm{P}_{\mathrm{m}}=$ Environmental impact contribution of personnel $(\mathrm{kg}) ; \mathrm{W}_{\mathrm{m}}=$ Total number of personnel (persons); $\lambda_{\mathrm{p}}=$ Environmental impact coefficient of personnel ( $\mathrm{kg} /$ working day $/$ person); $\mathrm{T}_{\mathrm{p}}=$ Total working hours of personnel (working day).

Environmental impact contribution of office facilities:

$$
\left.\mathrm{W}_{\mathrm{m}}=\sum_{\mathrm{i}}^{\mathrm{j}}\left\{\left[\mathrm{F}_{\mathrm{im}} \times \mathrm{T}_{\mathrm{i}} \times\left(1+\mathrm{L}_{\mathrm{i}}\right) \times \lambda_{\mathrm{i}}\right]+\cdots \cdots \cdot \mathrm{F}_{\mathrm{jm}} \times \mathrm{T}_{\mathrm{j}} \times\left(1+\mathrm{L}_{\mathrm{j}}\right) \times \lambda_{\mathrm{j}}\right]\right\}
$$

where $\mathrm{W}_{\mathrm{m}}=$ Environmental impact contribution of office facilities $(\mathrm{kg}) ; \mathrm{F}_{\mathrm{im}}, \mathrm{F}_{\mathrm{jm}}=$ Power consumption of office facilities $i, j(K w h) ; T_{i}, T_{j}=$ Working hours of office facilities $i, j(h)$; and $\mathrm{L}_{\mathrm{i}}, \mathrm{L}_{\mathrm{j}}=$ Electricity loss coefficient of facilities $\mathrm{i}, \mathrm{j}(\%)$.

SimaPro has been the world's leading life cycle assessment (LCA) software package for 30 years; it is trusted by industry and academics in more than 80 countries [57]. OpenLCA can access the social and economic impact of 15 different life cycles. The software has been widely used in various industries and research fields in Europe, the United States, Japan and the rest of the world; it is supported by databases such as Ecoinvent, Bedec, Soca, bridge design, construction drawings, and published research results.

\subsubsection{LCCA}

LCCA of bridges mainly includes initial cost, cost of maintenance, repair and replacement, casualties of personnel or loss of goods during operation, road use cost, and indirect loss of socio-economic benefits [58,59]. In order to accurately estimate these costs, it is necessary to clarify the degradation rate of bridge components and build a correct model for the designated fatigue life index $[60,61]$. Table 2 shows the maintenance cycle. The core elements of LCCA are financial factors, inter-generational responsibility, environmental aspects and sustainability, realising the optimal balance between safety, economic efficiency, and sustainability [62].

LCCA was conducted in accordance with the process of highway engineering in China, as shown in Figure 1. It was of equal importance to determine the life cycle cost, cost benefit, or cost risk by considering a variety of ways of calculating cost benefit [58]. 


$$
\mathrm{E}\left[\mathrm{C}_{\mathrm{T}}\left(\overline{\mathrm{x}}, \mathrm{T}_{\text {Ready }}\right)\right]=\mathrm{C}_{\mathrm{i}}(\overline{\mathrm{x}})+\sum_{\mathrm{t}=1}^{\mathrm{T} \text { Ready }}\left(\frac{\sum_{\mathrm{j}=1}^{\mathrm{J}} \mathrm{E}\left[\mathrm{C}_{\text {Advisory }}(\overline{\mathrm{x}}, \mathrm{t})\right]+\sum_{\mathrm{k}=1}^{\mathrm{K}} \mathrm{E}\left[\mathrm{C}_{\text {Assess }}(\overline{\mathrm{x}}, \mathrm{t})\right]+\sum_{\mathrm{l}=1}^{\mathrm{L}} \mathrm{E}\left(\mathrm{C}_{\text {Mixed }}(\overline{\mathrm{x}}, \mathrm{t})\right)}{(1+\mathrm{r})^{\mathrm{t}}}\right)
$$

where $\mathrm{E}\left[\mathrm{C}_{\mathrm{T}}\left(\overline{\mathrm{x}}, \mathrm{T}_{\text {Ready }}\right)\right]=$ LCCA cost in the preparatory stage (Chinese Yuan: CNY); $\mathrm{C}_{\mathrm{i}}(\overline{\mathrm{x}})=$ Direct cost in the preparatory stage $(\mathrm{CNY}) ; \sum_{j=1}^{\mathrm{J}} \mathrm{E}\left[\mathrm{C}_{\text {Advisoryj }}(\overline{\mathrm{x}}, \mathrm{t})\right]=$ Consulting fee of the development organisation $(\mathrm{CNY}) ; \sum_{\mathrm{k}=1}^{\mathrm{K}} \mathrm{E}\left[\mathrm{C}_{\text {Assess }}(\overline{\mathrm{x}}, \mathrm{t})\right]=$ Impact assessment fee of the development organisation $(\mathrm{CNY}) ; \sum_{l=1}^{\mathrm{L}} \mathrm{E}\left(\mathrm{C}_{\text {Mixed }}(\overline{\mathrm{x}}, \mathrm{t})\right)=$ Other costs incurred in the preparatory stage of the project, including expert review fee, transportation fee, approval procedure fee, office fee, labour fee for related personnel (CNY); and $r=$ Discount rate $(\%)$.

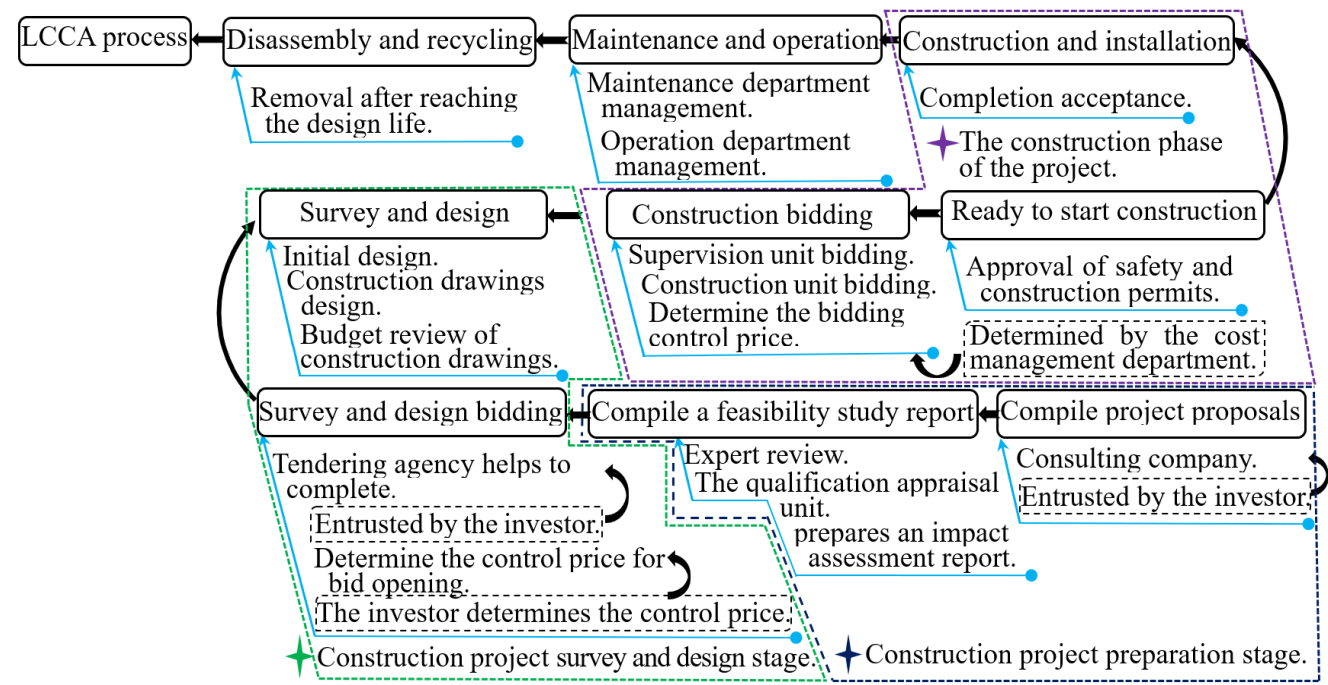

Figure 1. Basic procedure flow chart of highway engineering construction.

The service rate for the project-bidding agency issued by National Development and Reform Commission is given by [63]:

$\mathrm{C}_{\text {Bidding Service }}=$ $\left\{\begin{array}{l}500 \text { million } \mathrm{CNY} \leq \mathrm{C}_{\text {Build }}\left(\overline{\mathrm{x}}, \mathrm{T}_{\text {End }}\right) \leq 1000 \text { million } \mathrm{CNY} \\ 1000 \text { million } \mathrm{CNY}<\mathrm{C}_{\text {Build }}\left(\overline{\mathrm{x}}, \mathrm{T}_{\text {End }}\right) \leq 5000 \text { million } \mathrm{CNY} \\ 5000 \text { million } \mathrm{CNY}<\mathrm{C}_{\text {Build }}\left(\overline{\mathrm{x}}, \mathrm{T}_{\text {End }}\right) \leq 10,000 \text { million } \mathrm{CNY} \\ 10,000 \text { million } \mathrm{CNY}<\mathrm{C}_{\text {Build }}\left(\overline{\mathrm{x}}, \mathrm{T}_{\text {End }}\right) \\ \mathrm{C}_{\text {Bidding service }}=\text { Maximum amount } 3.5 \text { million } \mathrm{CNY}\end{array}\right.$

Costs of survey and design:
$\mathrm{C}_{\text {Design }}\left(\overline{\mathrm{x}}, \mathrm{T}_{\text {End }}\right)=$
$\mathrm{C}_{\mathrm{BS}}=0.006 \% * \mathrm{C}_{\text {Build }}$

$\mathrm{C}_{\mathrm{BS}}=0.004 \% * \mathrm{C}_{\text {Build }}$

3.0 million $\mathrm{CNY}, 4.5$ million $\mathrm{CNY}$ 


$$
\lambda_{\mathrm{h}}= \begin{cases}\mathrm{T}_{\text {Local }} \geq 35^{\circ} \mathrm{C} & \lambda_{\mathrm{h}}=1.2 \\ \mathrm{~T}_{\text {Local }} \leq-10^{\circ} \mathrm{C} & \lambda_{\mathrm{h}}=1.2 \\ 2000 \text { meters } \leq \mathrm{H}_{\text {Altitude }} \leq 3000 \text { meters } & \lambda_{\mathrm{h}}=1.1 \\ 3001 \text { meters } \leq \mathrm{H}_{\text {Altitude }} \leq 3500 \text { meters } & \lambda_{\mathrm{h}}=1.2 \\ 3501 \text { meters } \leq \mathrm{H}_{\text {Altitude }} \leq 4000 \text { meters } & \lambda_{\mathrm{h}}=1.3 \\ 4001 \text { meters } \leq \mathrm{H}_{\text {Altitude }} & \lambda_{\mathrm{h}} \gg 1.3 \text { (Negotiated price) }\end{cases}
$$

where $\mathrm{T}_{\text {Local }}=$ Ambient temperature of the place where the project locates $\left({ }^{\circ} \mathrm{C}\right)$, and $\mathrm{H}_{\text {Altitude }}=$ Altitude of the place where the project locates $(\mathrm{m})$.

Concerning the rate for the design and examination of construction drawings [63], it is charged by the budgetary investment ratio, thus the rate should not be higher than $2 \%$ of the budget amount of the project.

Construction costs:

$$
\mathrm{C}_{\text {Build }}\left(\overline{\mathrm{x}}, \mathrm{T}_{\text {End }}\right)=\mathrm{T}_{\mathrm{t}=\text { Start }}\left\{\frac{\mathrm{C}_{\text {Direct cost }}+\mathrm{C}_{\text {Extra charge }}+\left[\left(\mathrm{C}_{\text {Direct cost }}+\mathrm{C}_{\text {Extra charge }}\right) * \mathrm{C}_{\text {Profit }}\right]}{(1+\mathrm{r})^{\mathrm{t}}}\right\}\left[1 \pm\left(\mathrm{R}_{\mathbf{t}}\right)\right]
$$

where $\mathrm{C}_{\text {Build }}\left(\overline{\mathrm{x}}, \mathrm{T}_{\text {End }}\right)=$ LCCA cost in the stage of construction $(\mathrm{CNY}) ; \mathrm{C}_{\text {Direct cost }}=$ Direct cost of the project $(\mathrm{CNY}) ; \mathrm{C}_{\text {Extra charge }}=$ Indirect cost of the project $(\mathrm{CNY})$; and $\mathrm{C}_{\text {Profit }}=$ Construction profits of the project (CNY).

Costs of maintenance and operation:

Global warming and extreme weather events have resulted in observable effects on people, the environment, and civil infrastructures [6]. Stewart et al. proposed four main factors for infrastructure corrosion and structural performance deterioration, including temperature [65]. Barbara Rossi et al. concluded that the total project cost decreases with the increase in the discount rate, and the period of investment return ranges between 18.5 and 24.2 years [66].

The six bridges are located in five economic belts. Climate, traffic density, traffic accidents, load effect of heavy-duty vehicles, and natural disasters (such as flooding, ice damage, freezing damage and mudslides) have different degrees of impact on the maintenance costs of bridges. The analysis was carried out according to the Chinese Code for Maintenance of Highway Bridges and Culverts (JTG H11-2004), as shown in Table 1 [67,68].

Costs of maintenance and repair: $\mathrm{C}_{\text {Maintenance }}\left(\overline{\mathrm{x}}, \mathrm{T}_{100 \text { years }}\right)=$

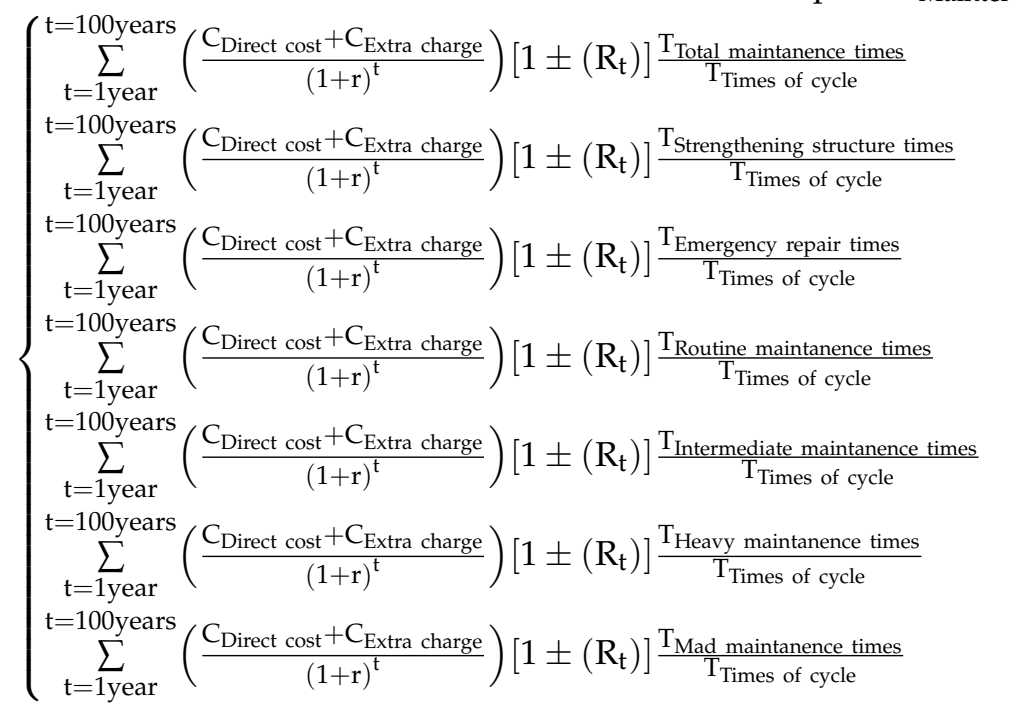

Maintenance costs

Strengthening structure costs

Emergency repair costs of road

Routine maintenance costs

Intermediate maintenance costs

Heavy maintenance costs

Mad improvement costs

where $\mathrm{C}_{\text {Maintenance }}\left(\overline{\mathrm{x}}, \mathrm{T}_{100}\right.$ years $)=$ Costs of maintenance and operation (CNY); $\mathrm{T}_{\text {Number of cycle }}$ represents the days of each maintenance cycle (days); and $\mathrm{T}_{\text {Total maintanence times, }}$ 
$\mathrm{T}_{\text {Strengthening structure times, }}, \mathrm{T}_{\text {Emergency repair times }}, \mathrm{T}_{\text {Routine maintanence times }}, \mathrm{T}_{\text {Med maintanence times }}$, $\mathrm{T}_{\text {Intermediate maintanence times, }}$ and $\mathrm{T}_{\text {Heavy maintanence times }}$ represent the total time for maintenance (days), the total time for strengthening (days), the total time of emergency repair (days), the total time for routine maintenance (days), the total time for intermediate maintenance (days), the total time for heavy maintenance (days), and the total time for overhaul maintenance (days), respectively.

Costs of traffic accidents:

Civilian car ownership in China reached 232,312,300 units in 2018, increasing by $42.7 \%$ since 2015 [69]. Wang et al. analysed the severity of traffic accidents in China from a macro perspective, finding that the total fatality rate and man-made injury rate of highway traffic accidents from 2000 to 2016 increased by $19.0 \%$ and $63.7 \%$ [70]. Vlegel et al. found that the average per capita health care cost was EU 8200 and the productivity cost was EU 5900 [71]. Rukaibi et al. estimated that the average cost of a traffic accident in Kuwait was $9122 \mathrm{KD} /$ crash (equivalent to EU 25,333.02) [72]. According to the data in the China Statistical Yearbook-2019, there were 244,937 traffic accidents in 2018, resulting in 63,194 deaths, 258,532 injuries, and direct property losses of CNY 1385 million [69].

$\mathrm{C}_{\text {Traffic accident }}\left(\overline{\mathrm{x}}, \mathrm{T}_{100 \text { years }}\right)=$

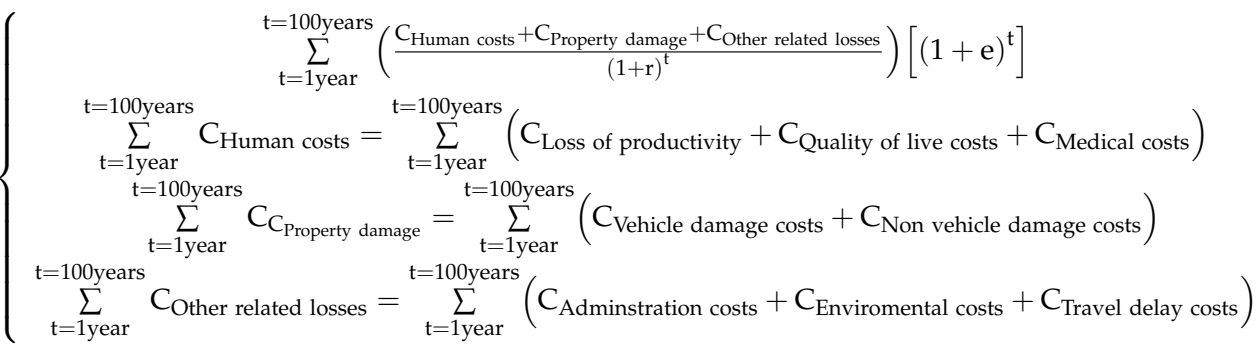

where $\mathrm{C}_{\text {Traffic accident }}\left(\overline{\mathrm{x}}, \mathrm{T}_{100 \text { years }}\right)=$ Cost of traffic accidents $(\mathrm{CNY}) ; \mathrm{C}_{\text {Human costs }}$; $\mathrm{C}_{\text {Property damage }} ; \mathrm{C}_{\text {Other related losses }}=$ Human costs $(\mathrm{CNY})$; property damage $(\mathrm{CNY})$; other related losses (CNY); and e = Economic growth rate $(\%)$.

The six bridges studied are municipal highway bridges and no traffic tolls were charged during the operation.

The total costs required in the stage of maintenance and operation are the sum of Equations (10) and (11).

Disassembly costs:

The cable-stayed bridges will be disassembled at the expiration of their designed service life. The modelling of incurred costs was subject to Eq. (4). The materials to be demolished include broken concrete, scrap steel and waste. Construction wastes dumped and stacked in the natural environment without authorisation are one of the sources of environmental pollution [73]. In recent years, countries all over the world have been using recycled materials for sustainable development and steel is re-smelted for recycling [74,75].

Recycling cost of waste and scraps:

$$
\mathrm{C}_{\text {Recycling }}\left(\overline{\mathrm{x}}, \mathrm{T}_{\text {Recycling }}\right)=\underbrace{\mathrm{t}=\text { New product }}_{\mathrm{t}=\text { Secondary processing }}\left[\frac{\mathrm{C}_{\text {Waste concrete }} * \mathrm{u}_{\text {Concrete }} * \mathrm{C}_{\text {Post-processing costs }+} \mathrm{C}_{\text {Waste steel }} * \mathrm{u}_{\text {Steel }} * \mathrm{C}_{\text {Steelmaking costs }}}{(1+\mathrm{r})^{\mathrm{t}}}\right]
$$

where $\mathrm{C}_{\text {Recycling }}\left(\overline{\mathrm{x}}, \mathrm{T}_{\text {Recycling }}\right)=$ Recycling costs of waste and scraps $(\mathrm{CNY}) ; \mathrm{C}_{\text {Waste concrete }}$ $=$ Quantity of demolished concrete waste $(\mathrm{kg}) ; \mathrm{u}_{\text {Concrete, }} \mathrm{u}_{\text {steel }}=$ Recovery rate of concrete and steel waste (\%); and $C_{\text {Steelmaking costs }}, C_{\text {Post-processing cost }}$ " 51 " = Cost of recycling and disposal (CNY/kg).

\subsubsection{SILA}

SILA witnessed its heyday from 1970 to 1980 and has been widely practiced in many fields around the world [76]. Social impact assessment comprises analysing, monitoring, 
and managing the social impacts of a project to bring about a more sustainable and equitable biophysical and human environment [77]. However, the assessment criteria and the quality of collected data are affected due to the limited resources of social assessment and the limited ability of regulatory agencies to control the management system [78,79].

PSILCA and USDA data and the Social Hotspots Database (SHDB) were used in this study to assess the research on sustainable social pillars [80,81]. The PSILCA database features the latest data sources, the original data sources and the quality assessment of risk data. Furthermore, the social contact messages from the PSILCA database can be associated with each other in the manner of SOCA (SOCA is an add-on for the Ecoinvent database, containing social inventory data based on PSILCA.) via Green Delta. The processes that are identical to those in environmental assessment can be used for social assessment, thus realising the coherence of the entire assessment (show in Figure 2). SILA uses input data from the LCIA for environmental and social assessment and determines 54 quantitative and qualitative indexes for 18 categories [82]. Five of the analysis indexes are closely related to the community stakeholders, according to the location where the six bridges are located and can be used as the factors for the social impact analysis. The five indexes are fatal accidents (FA), international migrant workers (IMW), youth illiteracy (YI), corruption (C), and sanitation coverage (SC).

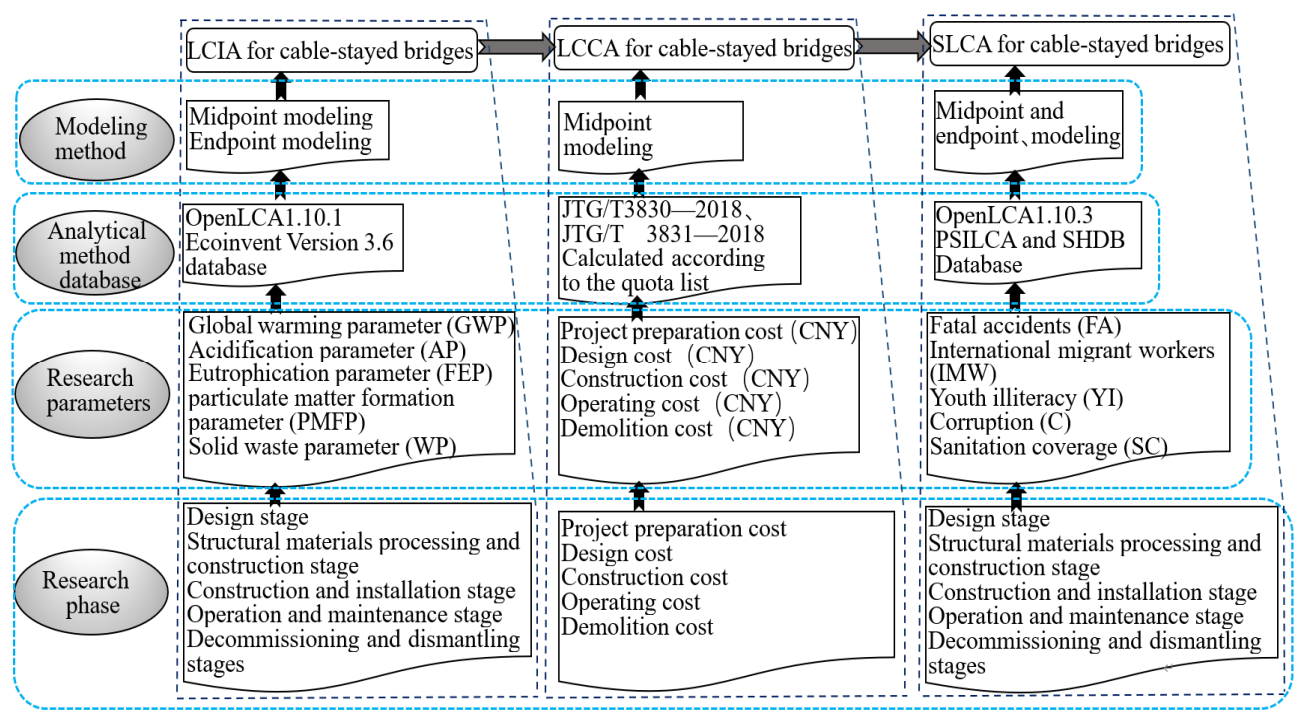

Figure 2. Schematic diagram of the LCIA, LCCA, and SILA analysis process.

According to the location of the six bridges in the region, the five indexes selected are closely linked to community stakeholders and can be used as factors for social impact analysis.

\subsection{Research Process}

The six cable-stayed bridges across five geographical zones of China (Northeast China, East China, Central China, South China, and Southwest China) and six provinces (Zhejiang, Guangdong, Sichuan, Hubei, Yunnan and Jilin) were selected as the objects of study [83]. They are important in terms of geographical location, economic value, environmental impact, and social assessment, becoming the strong backing for this study, as shown in Figure 3. 


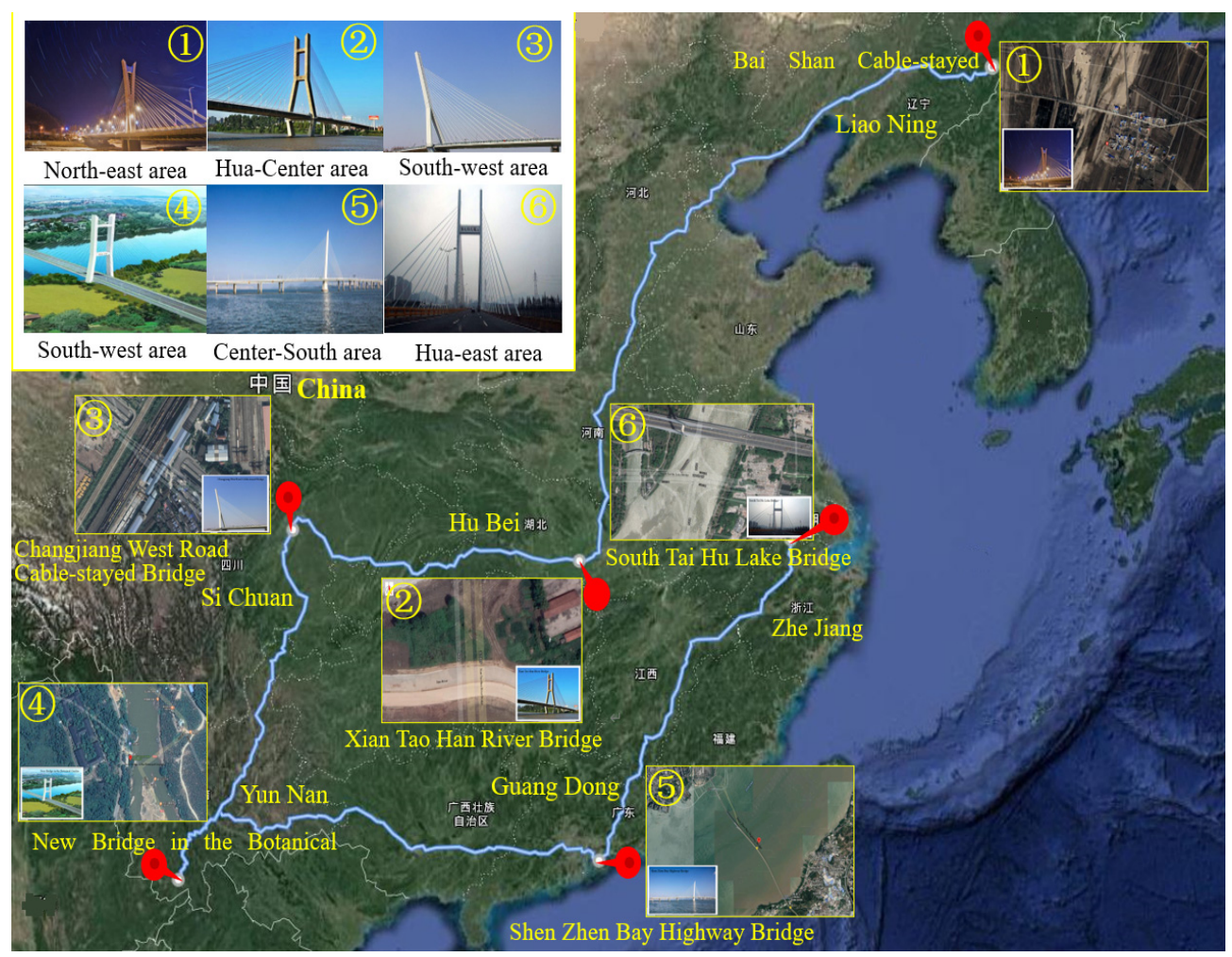

Figure 3. Schematic diagram of cable-stayed bridge regional distribution [83].

\subsubsection{LCIA}

General information about the six bridges is shown in Table 2. All of these bridges have been completed and put into operation. They are the main highway bridges of the cities where they are located.

The Chinese government classifies cities by criteria including the agglomeration degree of commercial resources, urban pivotability, resident activeness, lifestyle diversity and future plasticity [84]. Among these six cable-stayed bridges, STHB is located in a third-tier city, SZBB in a first-tier city, BGNB in a fourth-tier city, CJWB in a fourth-tier city, XTHB in a fifth-tier city, and BSCB in a fifth-tier city.

They were designed by six design institutes in different regions, which are between 84 and $2380 \mathrm{~km}$ away from the project sites. The surveying equipment used was self-owned, calibrated equipment with high precision, which needed to be transported by truck to the project site. The expressway is the preferred mode of transport, but rail travel should be adopted if the transport distance is larger than $500 \mathrm{~km}$. The development organisation was not allowed to use self-produced concrete for cable-stayed bridges, because the bridges are municipal works. All concrete used for the cable-stayed bridges had to be purchased as commercial concrete. Concrete is classified into C55, C50, C40, C30, C25 and C20. SZBB is a steel bridge, using $374 \mathrm{~m}^{3}$ of precast blocks of commercial concrete for the bridge deck.

During the construction, the materials were mainly transported and hoisted by a tower crane, a $25 \mathrm{~T} / 50 \mathrm{~T}$ truck crane, and a floating crane (for the sections across the river), because the main tower of the cable-stayed bridge was too high. The main beam of SZBB is made of Q345-C low alloy steel and the accessory structures are made of Q235-B steel. The components and parts were connected by high-strength bolts and welding. The bridge was divided into 31 beam sections, which were manufactured in the factory and then transported to the bridge position by barges. The floating crane and land cranes worked together to lift and install these sections in the right place. The other five cable-stayed bridges adopted reinforced concrete structures. The main towers were subject to cast-inplace construction with creeping formwork by sections. The main beams were subject to 
cast-in-place construction with a sliding formwork using the full framing method. The details are shown in Table 3.

BSCB is located in Baishan City, Jilin Province. The construction environment is affected by the local climate. The local temperature in winter can be as low as $-42{ }^{\circ} \mathrm{C}$, with an annual average temperature of $4.6^{\circ} \mathrm{C}$ [85]. Construction has to be stopped in October every year and can restart again by the end of April of the next year. The affected construction duration reaches 210 days a year.

The operation stage is the key period for the environmental impact contribution of bridges. A large number of vehicles will emit exhaust gases within the 100 years of service life, causing severe environmental pollution. Exhaust gas pollution is the key to research on LCIA. Dargay et al. concluded that the automobile saturation in China is 807 vehicles for every 1000 persons [86], which is set as the upper limit of the number of vehicles in each region. According to the study by Wu et al., car ownership will grow up to $4.8 \%$ in 2030 , with the growth rate in 2050 being $2.9 \%$, reaching 455 vehicles for every 1000 persons [87]. The traffic volume in 100 years is determined according to the comprehensive data analysis of the China Statistical Yearbook [88], as shown in Figure 4.

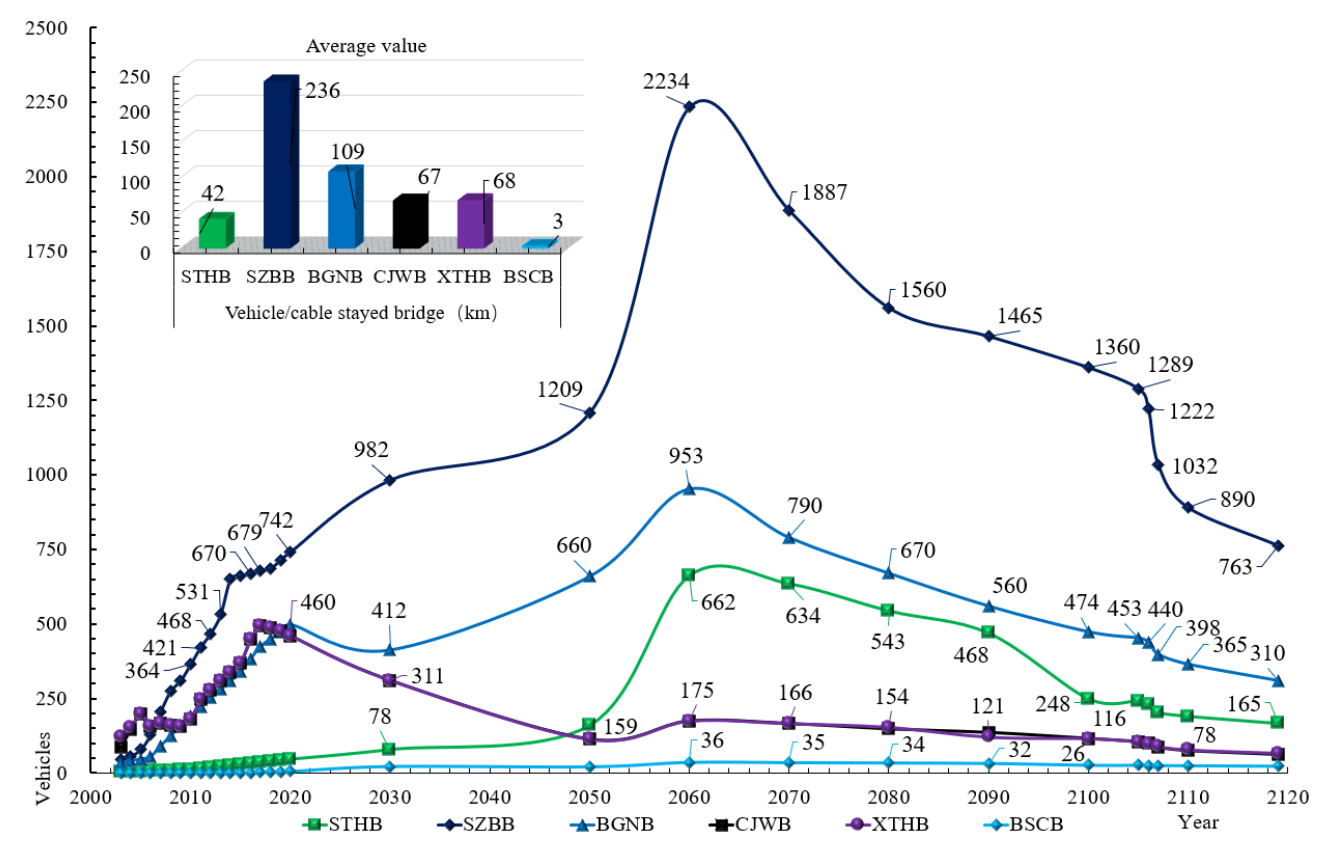

Figure 4. Schematic diagram of the number of vehicles driving on six cable-stayed bridges. 
Table 3. Cable-stayed bridge engineering data statistics table.

$\begin{array}{lll}\text { Bridge Name } & \text { Regional Location } & \text { Basic Situation }\end{array}$

South Tai Hu Lake Bridge (338 m)

East China, Huzhou in Zhejiang
The main bridge is a double-cable, plane H-shaped, single-tower, concrete, cable-stayed bridge with a span layout of

$160+190+38 \mathrm{~m}$, an urban expressway level, and a design speed of $60 \mathrm{Km} / \mathrm{h}$. The standard section width of the bridge is $40.5 \mathrm{~m}$. The main beam adopts the cross-section form of double main ribs, the building height is $3.055 \mathrm{~m}$, the full width is $40.5 \mathrm{~m}$, and the standard main rib is $2.7 \mathrm{~m}$ high and $1.7 \mathrm{~m}$ wide. The transverse partition is $0.28 \mathrm{~m}$ wide; the bridge deck is $28 \mathrm{~cm}$ thick, and each cable plane has 24 pairs of cables.

The North Channel Bridge adopts the "180 + $90+75 \mathrm{~m}$ " span layout, the main beam adopts bolt-welded streamlined steel box girder, the beam height is $4.12 \mathrm{~m}$, the standard section length is $12 \mathrm{~m}$, and the overall width is $38.6 \mathrm{~m}$. The total height of the pylon is $139.053 \mathrm{~m}$. The main beam adopts a single-box, four-chamber, thin-walled structure composed of steel box beams with cantilever arms. The top plate thickness of the bridge deck is $18 \mathrm{~mm}$; the bottom plate is $12-20 \mathrm{~mm}$. The bridge has a total of 12 pairs of stay cables with a cable distance of $3 \mathrm{~m}$ and a standard cable distance of $12 \mathrm{~m}$.

\section{Bridge Layout Drawing}
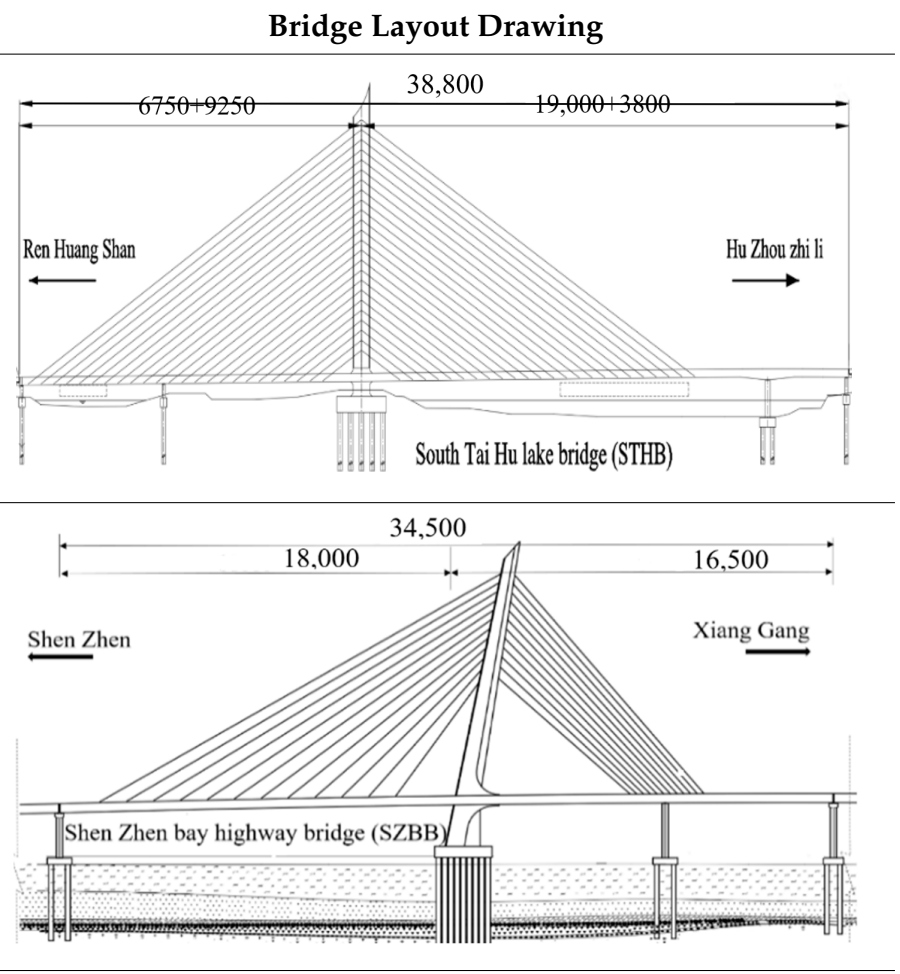

Shenzhen Bay Bridge (345 m)
Central and South China, Shenzhen Bay 
Table 3. Cont.

\section{Bridge Name}

Regional Location

Basic Situation

The main bridge is an elliptical steel box with a concrete tower column, double cable plane, cable-stayed bridge with a span of $75+90 \mathrm{~m}$ and a total length of $165 \mathrm{~m}$. The side span is $75 \mathrm{~m}$ and the main span is $90 \mathrm{~m}$. The full width of the bridge deck is

New Bridge of

Xishuangbanna Tropical

Botanical Garden (225 m)

\section{Southwest China,}

Xishuangbanna Prefecture

$1.2 \mathrm{~m}$, the outer top and bottom width is $1.55 \mathrm{~m}$, and the bridge deck is $22 \mathrm{~cm}$ thick. The tower column of the cable-stayed bridge adopts a steel box concrete structure with a cross section of $2.5^{*} 4.0 \mathrm{~m}$ and a steel plate thickness of $20 \mathrm{~mm}$.

Single tower, single cable, plane cable-stayed bridge without back cable, main span $108 \mathrm{~m}$, side span $27.7 \mathrm{~m}$, harp-shaped cable surface, tower and beam consolidation. The standard cable distance on the beam is $8 \mathrm{~m}$, the standard section is $8 \mathrm{~m}$ long and weighs about 300 Tons. The main beam adopts a pre-stressed concrete, single-chamber, three-box, flat, thin-walled box beam. The top plate of the box is $24 \mathrm{~m}$ wide; the bottom plate is $8.4 \mathrm{~m}$ wide, the beam height is $2.5 \mathrm{~m}$, the top plate thickness is $24 \mathrm{~cm}$, the bottom plate thickness is $30 \mathrm{~cm}$, the inclined web plate thickness is $22 \mathrm{~cm}$, and the vertical web plate thickness is $30 \mathrm{~cm}$. A horizontal partition is set every $4 \mathrm{~m}$ with a thickness of $28 \mathrm{~cm}$. The approach bridge adopts multi-span continuous beams, all of which are $20 \mathrm{~m}$ in span, and the main beam is a $1.4 \mathrm{~m}$ high box girder.
Cable-stayed Bridge of

Deyang City (136 m)
Southwest China

Deyang City
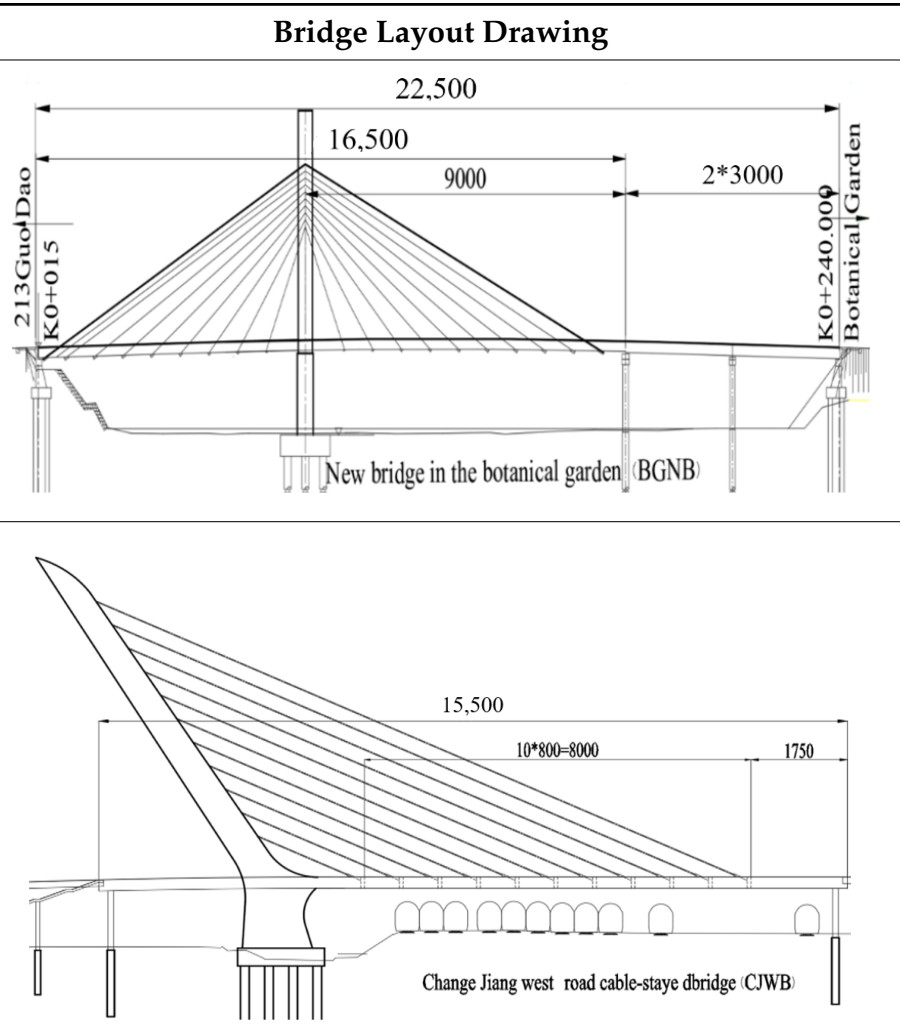
Table 3. Cont.

Bridge Name

Hanjiang Highway Bridge

in Xiantao City (312 m)

Central China, Xiantao City

The main bridge is a $50+82+180 \mathrm{~m}$, three-span, single-tower, double-cable plane cable-stayed bridge, the main girder has a full cross-section width of $25.6 \mathrm{~m}$, a basic section length of $8 \mathrm{~m}$,

a basic width of side ribs of $1.8 \mathrm{~m}$, and a basic spacing of $8 \mathrm{~m}$

between the diaphragms. The roof thickness of the main beam is

$0.30 \mathrm{~m}$, and the beam height is $1.9 \mathrm{~m}$.

The main bridge is a two-span, single-cable, plane cable-stayed bridge with a span of $85+85 \mathrm{~m}$. The main beam adopts a single box three-chamber section, the beam height is $2.0 \mathrm{~m}$, the thickness of the top plate is $20 \mathrm{~cm}$, and the thickness of the bottom plate is $40 \mathrm{~cm}$. The section of the main tower adopts an " $\mathrm{H}$ " shaped cross-section concrete tower column. Oblique cable harp layout, single-cable deck bridge type, double-width layout with a net width of $15.5 \mathrm{~m}$ and a total width of $23.3 \mathrm{~m}$.
Baishan Bridge in Baishan City $(410 \mathrm{~m})$

Northeast China

Baishan City
Bridge Layout Drawing
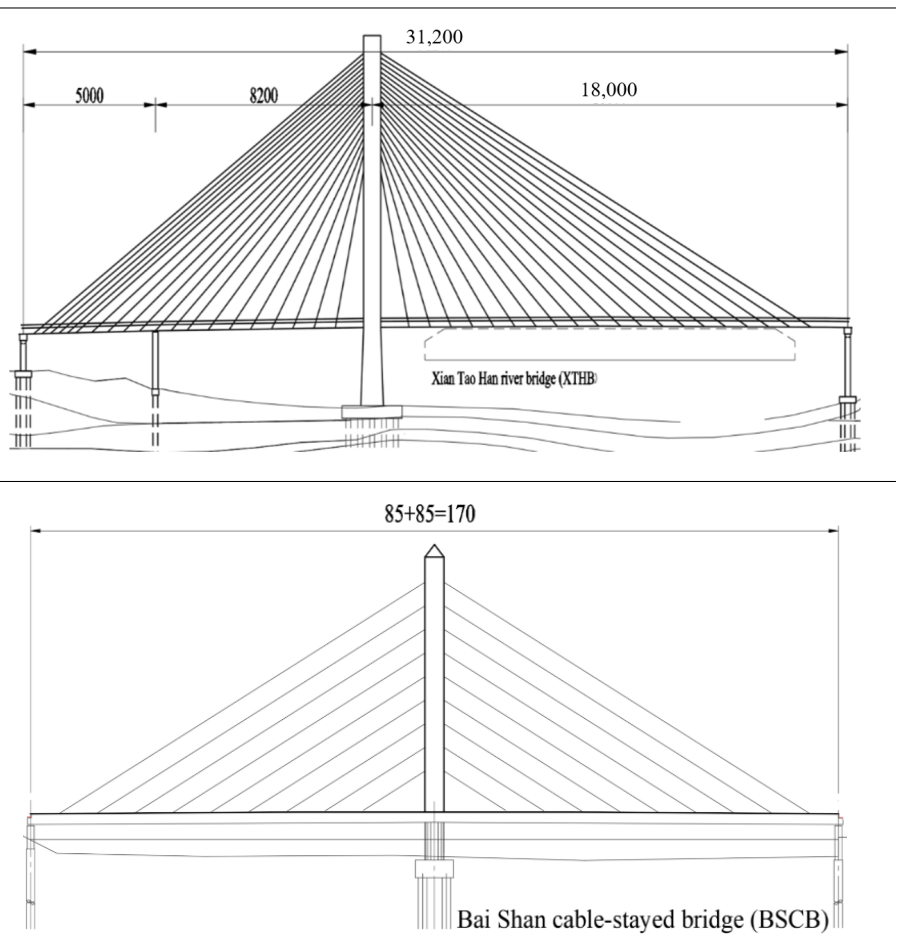
Establish a traffic flow analysis model:

$$
\mathrm{N}_{\mathrm{V}}\left(\mathrm{x}, \mathrm{T}_{\mathrm{SO}}^{\mathrm{SD}}\right)=\left\{\begin{array}{c}
\mathrm{T}_{\mathrm{C}}^{\mathrm{D}} \\
\mathrm{N}_{\mathrm{P}_{\mathrm{T}}}^{\mathrm{P}_{\mathrm{T}}}\left(\lambda 1_{\mathrm{GR}}\right) \\
\mathrm{N}_{\mathrm{H}}\left[\mathrm{T}_{\text {Quantity of the } \mathrm{Y}}^{\mathrm{Urban} \mathrm{H} \text { in 100 } \mathrm{Y}}\left(\lambda 2_{\mathrm{GR}}\right)\right] \\
\mathrm{N}_{\mathrm{N} \text { of } \mathrm{V}\left[\mathrm{v}_{\mathrm{C}}^{100 \mathrm{Y}}\left(\lambda 3_{\mathrm{GR}}\right)\right]} \mathrm{N}_{1000 \text { persons }}^{\mathrm{N} \text { of } \mathrm{V}} \\
\mathrm{N}_{\text {Every } \mathrm{Y}}^{\text {The } \mathrm{N} \text { of } \mathrm{V} \text { passing on the bridge }}=\times \mathrm{L}_{\text {Bridge }}
\end{array}\right.
$$

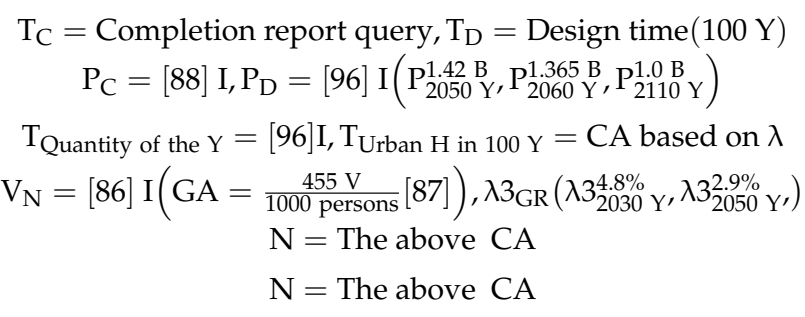

where $\mathrm{B}=$ Billion; $\mathrm{CA}=$ Calculated; $\mathrm{C}=$ Completed; $\mathrm{D}=$ Disassembly; $\mathrm{GA}=$ Greatest amount; $\mathrm{GR}=$ Growth rate; $\mathrm{H}=$ Highways; $\mathrm{I}=$ Inquiry; $\mathrm{N}=$ Number; $\mathrm{P}=$ Population; $\mathrm{SD}=$ Start disassembly; $\mathrm{SO}=$ Start operation; $\mathrm{V}=$ Vehicles; and $\mathrm{Y}=$ Years. (Note: this abbreviation is only used in Equation (13)).

Figure 4 and Equation (13) show that the traffic volume of SZBB and BGNB is 2 to 5 times that of the traffic volume of the other four bridges, which will affect the subsequent environmental pollution data of the bridges. After 2000, infrastructure expenditure in China accounted for approximately $6.5 \%$ of gross domestic product (GDP), much higher than the average level of $4 \%$ in other developing countries. After 2009, coastal provinces and cities increased investment in infrastructure (including energy, transportation, telecommunications, water and sewage treatment), reaching 15-20\% of GDP [89].

After the expiration of the operation stage, the cable-stayed bridges enter the disassembly stage. These bridges will be demolished by mechanical disruption because blasting demolition has many safety-impacting factors and these bridges are all located in urban areas. The scrapped steel materials will be transported to steel works for recycling. Concrete blocks will be transported to the production plants of reclaimed materials for crushing and classification. All of the remaining waste will be transported to the waste treatment plant for recycling.

\subsubsection{LCCA}

All of these cable-stayed bridges are municipal works, so the construction costs are analysed based on Engineering Standards for China's Transportation Industry, JTG 3830-2018 Measures for Preliminary Estimate/Budgeting of Highway Projects, and JTG/T 3831-2018 Norms for Preliminary Estimate of Highway Projects [90].

The construction cost is first calculated by Equation (9), in accordance with design drawings, bill of quantities, and norms for preliminary estimates of highway projects. As shown in Table 4, the construction costs of the cable-stayed bridges were: CNY 72,055,116.25 for STHB, CNY 103,996,538.70 for SZBB, CNY 18,803,871.58 for BGNB, CNY 24,721,480.22 for CJWB, CNY 47,164,942.89 for XTHB, and CNY 37,812,245.23 for BSCB, respectively. 
Table 4. Statistical table of construction cost of six cable-stayed bridge projects ([91]). Unit: CNY.

\begin{tabular}{|c|c|c|c|c|c|c|c|c|c|}
\hline Number & Cost Incurred & Ratio & $\begin{array}{l}\text { Calculation } \\
\text { Method }\end{array}$ & STHB & SZBB & BGNB & CJWB & ХТНВ & BSCB \\
\hline 1 & Direct project cost & & & $63,392,933.82$ & $92,208,319.2$ & $15,353,271.88$ & $20,691,737.1$ & $40,938,707.24$ & $32,501,337.6$ \\
\hline 2 & Insurance fee & & & $1,901,788.015$ & $2,766,249.576$ & $460,598.1564$ & $620,752.114$ & $1,228,161.217$ & $975,040.129$ \\
\hline $2-1$ & $\begin{array}{l}\text { Project insurance stipulated } \\
\text { in the contract }\end{array}$ & $2.50 \%$ & $1 * 2(2-1)$ & $1,584,823.346$ & 2,305,207.98 & $383,831.797$ & $517,293.428$ & $1,023,467.681$ & $812,533.441$ \\
\hline $2-2$ & $\begin{array}{l}\text { Third-party liability } \\
\text { insurance stipulated in } \\
\text { the contract }\end{array}$ & $0.50 \%$ & $1 * 2(2-2)$ & $316,964.6691$ & $461,041.596$ & $76,766.3594$ & $103,458.686$ & $204,693.5362$ & $162,506.688$ \\
\hline 4 & $\begin{array}{l}\text { environmental } \\
\text { protection fees }\end{array}$ & $1,000,000$ & Constant cost & $1,000,000$ & $1,000,000$ & $1,000,000$ & $1,000,000$ & $1,000,000$ & $1,000,000$ \\
\hline 5 & Safety production fees & $1.50 \%$ & $1 * 5$ & $950,894.0074$ & $1,383,124.788$ & $230,299.0782$ & $310,376.057$ & $614,080.6085$ & $487,520.064$ \\
\hline 6 & $\begin{array}{l}\text { Engineering management } \\
\text { software (temporary } \\
\text { estimate) }\end{array}$ & 100,000 & Constant cost & 100,000 & 100,000 & 100,000 & 100,000 & 100,000 & 100,000 \\
\hline 7 & $\begin{array}{l}\text { Application fee for } \\
\text { building information } \\
\text { model technology }\end{array}$ & 100,000 & Constant cost & 100,000 & 100,000 & 100,000 & 100,000 & 100,000 & 100,000 \\
\hline 8 & $\begin{array}{l}\text { Temporary road } \\
\text { construction, maintenance } \\
\text { and dismantling fees }\end{array}$ & & & $101,428.6941$ & $147,533.3107$ & $24,565.23501$ & $33,106.7794$ & $65,501.93158$ & $52,002.1402$ \\
\hline $8-1$ & $\begin{array}{l}\text { Fees for the construction, } \\
\text { maintenance and } \\
\text { dismantling of the } \\
\text { original roads }\end{array}$ & $0.08 \%$ & $1 * 8(8-1)$ & $50,714.34706$ & $73,766.65536$ & $12,282.6175$ & $16,553.3897$ & $32,750.96579$ & $26,001.0701$ \\
\hline $8-2$ & $\begin{array}{l}\text { Construction, maintenance } \\
\text { and dismantling fees of } \\
\text { temporary steel trestle } \\
\text { and wharf }\end{array}$ & $0.08 \%$ & $1 * 8(8-2)$ & $50,714.34706$ & $73,766.65536$ & $12,282.6175$ & $16,553.3897$ & $32,750.96579$ & $26,001.0701$ \\
\hline 9 & $\begin{array}{l}\text { Temporarily occupying } \\
\text { land and occupying } \\
\text { the river }\end{array}$ & $0.25 \%$ & $1 * 9$ & $158,482.3346$ & $230,520.798$ & $38,383.1797$ & $51,729.3428$ & $102,346.7681$ & $81,253.3441$ \\
\hline
\end{tabular}


Table 4. Cont.

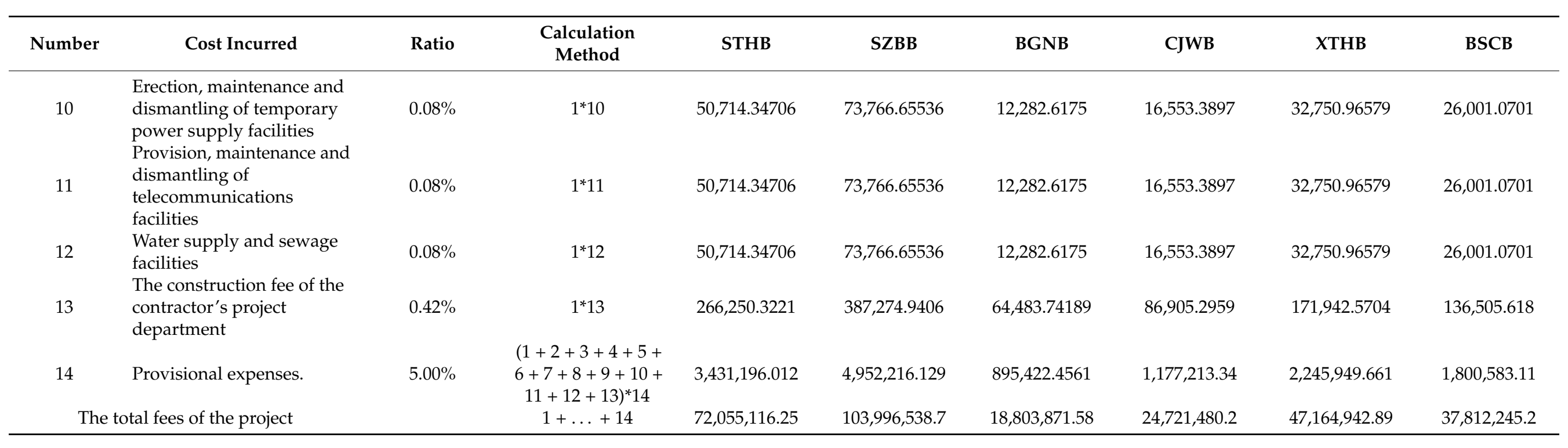


In the operation stage, aging parts and components need to be repaired and replaced in the bridges. Table 1 presents the maintenance and repair cycles of the main components. The costs generated by multiple replacements will be included in the costs for the construction stage, and the economic growth coefficient can then be considered.

The costs of traffic accidents are mainly used to analyse losses caused by traffic accidents and related expenses. According to the Chinese transportation statistics [32], the incidence of traffic accidents from 2001 to 2018 dropped by $25.7 \%$, resulting in the reduction in property losses by $29.3 \%$. After 2014, the annual reduction rate of traffic accidents stayed between $0.4 \%$ and $-0.7 \%$, and the property losses remained at CNY 5600 per accident.

As shown in Table 5, LCCA was conducted in three stages. The first stage covered the years from 2003 to 2018 . The costs of traffic accidents were analysed based on the existing data. The coefficient for the growth or reduction rate of traffic accidents in 15 years, and the annual average number of traffic accidents were also determined. The second stage covered the years from 2019 to 2030. In 2030, the population of China will reach its peak and so will the level of car ownership (Figure 4). The population and car ownership will begin to decline after 2031 and the accident rate will tend to be stable.

Table 5. Statistical table of loss from traffic accidents of six bridges during operation ([32]).

\begin{tabular}{|c|c|c|c|c|}
\hline Bridge Name & $\begin{array}{l}\text { Time Period } \\
\text { (Years) }\end{array}$ & $\begin{array}{l}\text { Accident Loss } \\
\text { (CNY/Time) }\end{array}$ & $\begin{array}{l}\text { Times of } \\
\text { Accidents }\end{array}$ & $\begin{array}{l}\text { Comprehensive } \\
\text { Loss Fee (CNY) }\end{array}$ \\
\hline STHB & $\begin{array}{l}\text { 2006 2018, } \\
2019 \sim 2030, \\
2031 \sim 2105\end{array}$ & 3866 & $693 \backslash 659 \backslash 460$ & $7,005,192$ \\
\hline SZBB & $\begin{array}{l}\text { 2007 2018, } \\
2019 \sim 2030, \\
2031 \sim 2106\end{array}$ & 3259 & $268 \backslash 255 \backslash 179$ & $2,287,818$ \\
\hline BGNB & $\begin{array}{l}\text { 2006 2018, } \\
\text { 2019 2030, } \\
2031 \sim 2105\end{array}$ & 4831 & $301 \backslash 286 \backslash 201$ & $3,806,828$ \\
\hline CJWB & $\begin{array}{l}\text { 2005 2018, } \\
\text { 2019 2030, } \\
2031 \sim 2104\end{array}$ & 8706 & $1070 \backslash 1019 \backslash 718$ & $24,437,742$ \\
\hline ХТНВ & $\begin{array}{l}\text { 2003 2018, } \\
\text { 2019 2030, } \\
2031 \sim 2102\end{array}$ & 6885 & $262 \backslash 250 \backslash 175$ & $4,730,682$ \\
\hline BSCB & $\begin{array}{l}\text { 2019 2030, } \\
\text { 2031 2118 }\end{array}$ & 7213 & $456 \backslash 434 \backslash 306$ & $8,626,748$ \\
\hline
\end{tabular}

\subsubsection{SILA}

As shown in Figure 2, SILA was also conducted in five stages. The impact of the bridges on communities was analysed for all aspects, from the design stage to the final disassembly stage. The International Finance Corporation's Performance Standards on Social and Environmental Sustainability (IFC 2012a) was taken as the reference. These Standards has become globally recognised good practice for handling environmental and social risk management and has been adopted by more than 80 leading banks as the "gold standard" for guiding project development [92,93]. The Standards formulate eight performance standards, including social and environmental assessment and management systems, labour and working conditions, pollution prevention and abatement, community health, safety and security, land acquisition and involuntary resettlement, biodiversity conservation and sustainable natural resource management, indigenous peoples, and cultural heritage. Based on the characteristics of Chinese communities (aboriginals will not be considered, because there are no aboriginals in the communities where cable-stayed bridges are located, and cultural heritage will also not be considered, because there is no newly-built cultural heritage in the construction areas), and the latest assessment factors in the PSILCA database, five assessment standards were selected as the research parameters, in accordance with the conclusions of comprehensive analysis (see Figure 2). 


\section{Results and Discussion}

\subsection{LCIA}

According to our findings (shown in Table 6), the GWPs of six bridges are the main sources of environmental pollution, accounting for over $92 \%$ of the total pollution of each bridge. This is why the authors chose these five parameters in the long-term research. Effective control of GWP is the top priority for alleviating global pollution.

Table 6. Life cycle assessment (LCA) statistical tables for six cable-stayed bridges. Unit: $\mathrm{kg}$.

\begin{tabular}{cccccc}
\hline $\begin{array}{c}\text { Bridge } \\
\text { Name }\end{array}$ & GWP & AP & FEP & PMFP & WP \\
\hline STHB & $285,792,121.03$ & $758,359.05$ & $778,387.38$ & $2,755,862.99$ & $4,202,670.97$ \\
SZBB & $75,192,817.81$ & $538,510.86$ & $445,853.55$ & $1,469,182.83$ & $3,451,343.80$ \\
BGNB & $69,261,736.42$ & $214,170.43$ & $251,077.34$ & $756,768.56$ & $1,397,595.57$ \\
CJWB & $80,429,187.06$ & $236,629.18$ & $264,255.94$ & $845,577.45$ & $1,414,549.54$ \\
XTHB & $167,606,486.66$ & $424,005.32$ & $502,313.61$ & $1,559,831.83$ & $2,530,246.34$ \\
BSCB & $151,598,681.32$ & $322,031.97$ & $424,120.38$ & $1,219,842.08$ & $1,917,809.39$ \\
\hline
\end{tabular}

Figure 5 shows the environmental impact contributions of the six cable-stayed bridges, in the maintenance and operation stage, as follows: STHB $=209,488.94$ tonnes $>$ XTHB $=133,511.65$ tonnes $>\mathrm{BSCB}=126,010.36$ tonnes $>\mathrm{CJWB}=648,518$ tonnes $>\mathrm{BGNB}=$ $49,735.66$ tonnes $>$ SZBB $=1230.24$ tonnes.

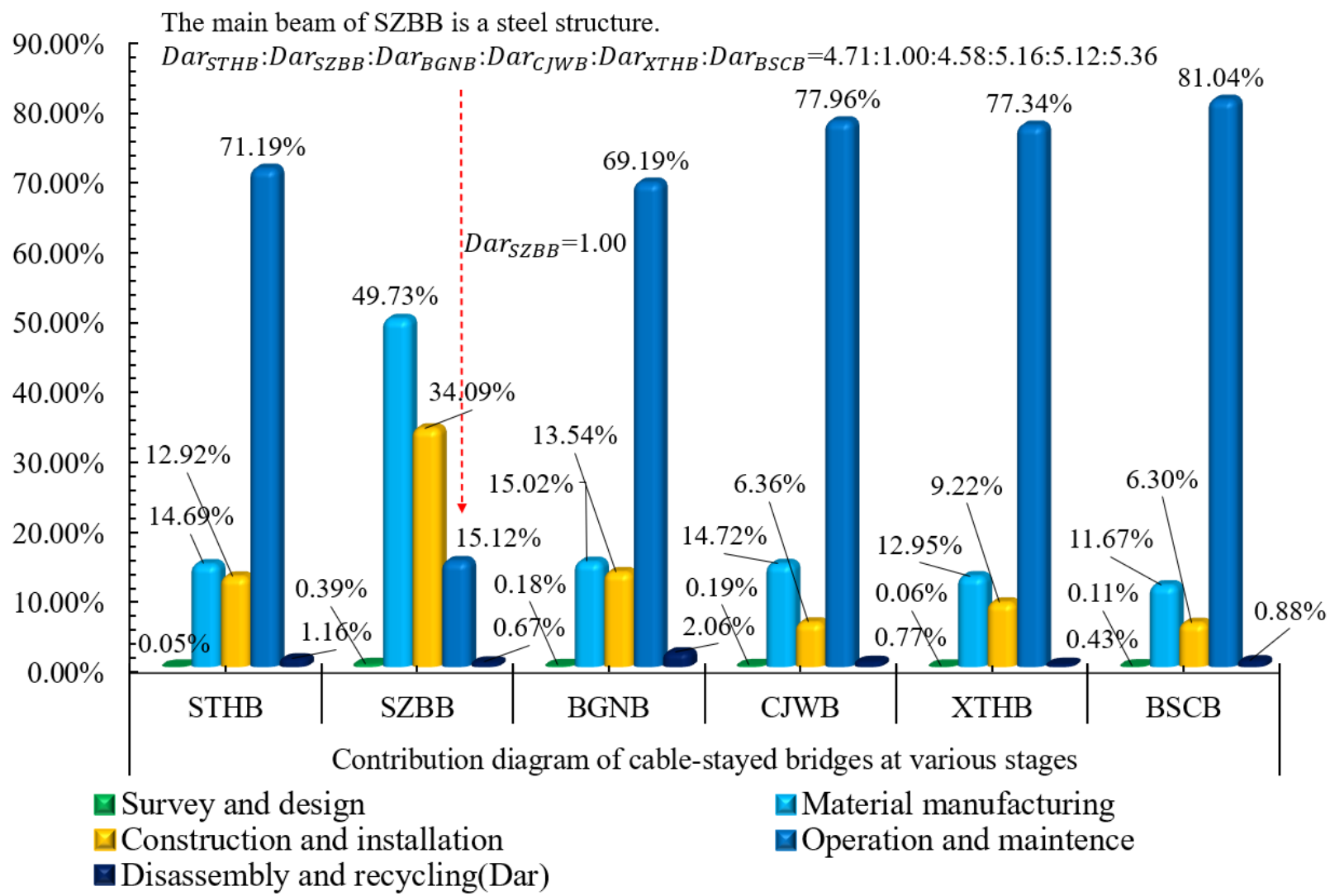

Figure 5. Environmental impact contribution diagrams of six cable-stayed bridges at various stages.

An interesting research finding is that the main beam of SZBB is a steel structure, Environmental impact contribution material manufacturing stage $>$ Maintenance and operation

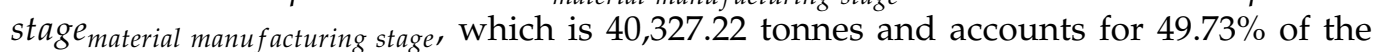
total contribution of SZBB. This finding also proves that the environmental impact con- 
tribution of the steel bridge mainly comes from the material manufacturing stage and the construction and installation stage, accounting for $83.82 \%$ of the total contribution. Although there is a huge difference between the environmental impact contribution of a steel bridge and that of a concrete bridge, the total environmental impact contribution of the two kinds of bridges are approximate to each other.

\subsection{Comparison}

The differences in the durability of building materials and standards between Europe and China result in a difference in the life span of bridges, and the difference is mainly manifested in the service life of concrete; the warranty period of concrete for stay cables in Europe is 100 years, while in China, it is 20 or 50 years $[67,94]$.

Thus, a large amount of maintenance and replacement work is required, resulting in great changes in environmental pollution values during the maintenance period.

Table 7 shows the environmental impact contribution values of five impact factors in the maintenance stage. Subject to the European and Chinese design standards, the maximum value falls on $G W P_{\text {European standard }}=5343.68$ tonnes for $\mathrm{SZBB}$ and $G W P_{\text {Chinese standard }}=19,736.99$ tonnes for STHB. Interestingly, the value of SZBB's steel structure under the European standard is $10,824.72$ tonnes greater than that under the Chinese standard. The difference in the design life of the materials leads to 33- to 73-fold differences, in terms of the environmental pollution value in the maintenance stage, and this is just a comparison analysis for one stage.

Table 7. Environmental pollution data in Europe and China during the maintenance phase. Unit: kg.

\begin{tabular}{ccc}
\hline Bridge Name & $\begin{array}{c}\text { Quantity Analysed According to } \\
\text { Chinese Standards }\end{array}$ & $\begin{array}{c}\text { Quantity Analysed According to } \\
\text { European Standards }\end{array}$ \\
\hline STHB & $202,577,714.70$ & $4,060,953.15$ \\
SZBB & $8,469,275.96$ & $5,413,303.55$ \\
BGNB & $46,427,579.22$ & $1,264,900.09$ \\
CJWB & $61,909,222.65$ & $1,857,067.35$ \\
XTHB & $127,556,952.20$ & $3,689,371.79$ \\
BSCB & $120,405,196.80$ & $1,648,154.08$ \\
\hline
\end{tabular}

Figure 6 shows the difference in the environmental pollution value for the six bridges under five environmental impact factors and subject to two standards. The replacement times of the exposed stable cables and concrete of the cable-stayed bridges in the 100 years of the service life increases with time, resulting in an increase in GWP by 3249 15761 tonnes, particularly the GWP of the steel bridge at SZBB, which reduces by 4568 tonnes. The pollution contributions of the six cable-stayed bridges increase by $549,412.2$ tonnes in total, which is an amazing figure. 


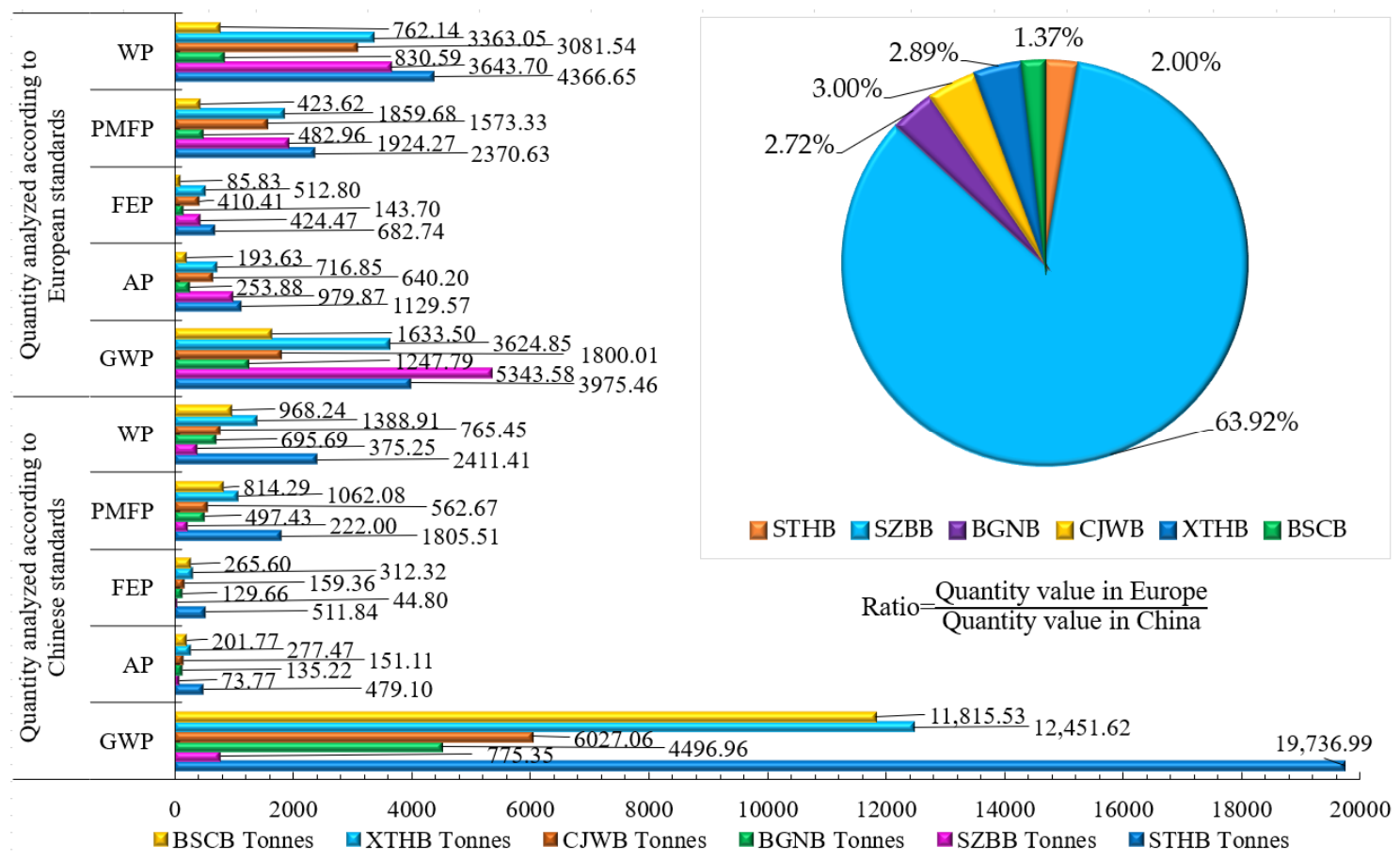

Figure 6. Environmental impact contribution diagrams of six cable-stayed bridges at various stages.

\section{3. $L C C A$}

The conclusions of LCCA are shown in Table 8. The bridges selected in the case analyses are located in China, so the norms for Chinese highways were used in each analysis. For the cable-stayed bridges with reinforced concrete structures, the cost ratio of the maintenance and operation stage remains between $49 \%$ and $64 \%$. However, the cost of steel bridges in the construction stage accounts for $63.2 \%$ of the total expenses because of the high investment cost. The maintenance cost of the steel bridge is $30 \%$ lower than that of the concrete bridge. The main reason is that the steel structure is superior to the concrete structure in terms of durability.

Table 8. Statistical table of the cost ratio of 6 cable-stayed bridges.

\begin{tabular}{ccccccc}
\hline Cost Name & STHB & SZBB & BGNB & CJWB & XTHB & BSCB \\
\hline Cost of project preparation & $0.01 \%$ & $0.02 \%$ & $0.01 \%$ & $0.01 \%$ & $0.01 \%$ & $0.01 \%$ \\
Survey and design costs & $0.07 \%$ & $0.13 \%$ & $0.06 \%$ & $0.05 \%$ & $0.06 \%$ & $0.06 \%$ \\
Project construction costs & $33.63 \%$ & $63.20 \%$ & $28.29 \%$ & $24.39 \%$ & $30.40 \%$ & $29.99 \%$ \\
Maintenance and & $60.57 \%$ & $33.56 \%$ & $63.69 \%$ & $49.94 \%$ & $63.78 \%$ & $60.00 \%$ \\
operating costs & $3.27 \%$ & $1.39 \%$ & $5.73 \%$ & $24.11 \%$ & $3.05 \%$ & $6.84 \%$ \\
Accident costs & $2.45 \%$ & $1.69 \%$ & $2.23 \%$ & $1.50 \%$ & $2.69 \%$ & $3.10 \%$ \\
Demolition stage costs & & & & & & \\
\hline
\end{tabular}

As shown in Figure 7, the maintenance cost of STHB is CNY 120 million, which is 1.8 times the construction cost. The maintenance costs of BGNB, CJWB, XTHB and BSCB are 2.0 to 2.3 times their construction costs. For the cable-stayed bridges with the reinforced concrete structure, the stay cables and concrete need to be replaced two to five times, because their service life and durability ranges between 20 and 50 years. Costs for multiple replacement events are the primary reason for the excessive maintenance costs, so the key to reducing costs is to improve the service life of materials. 


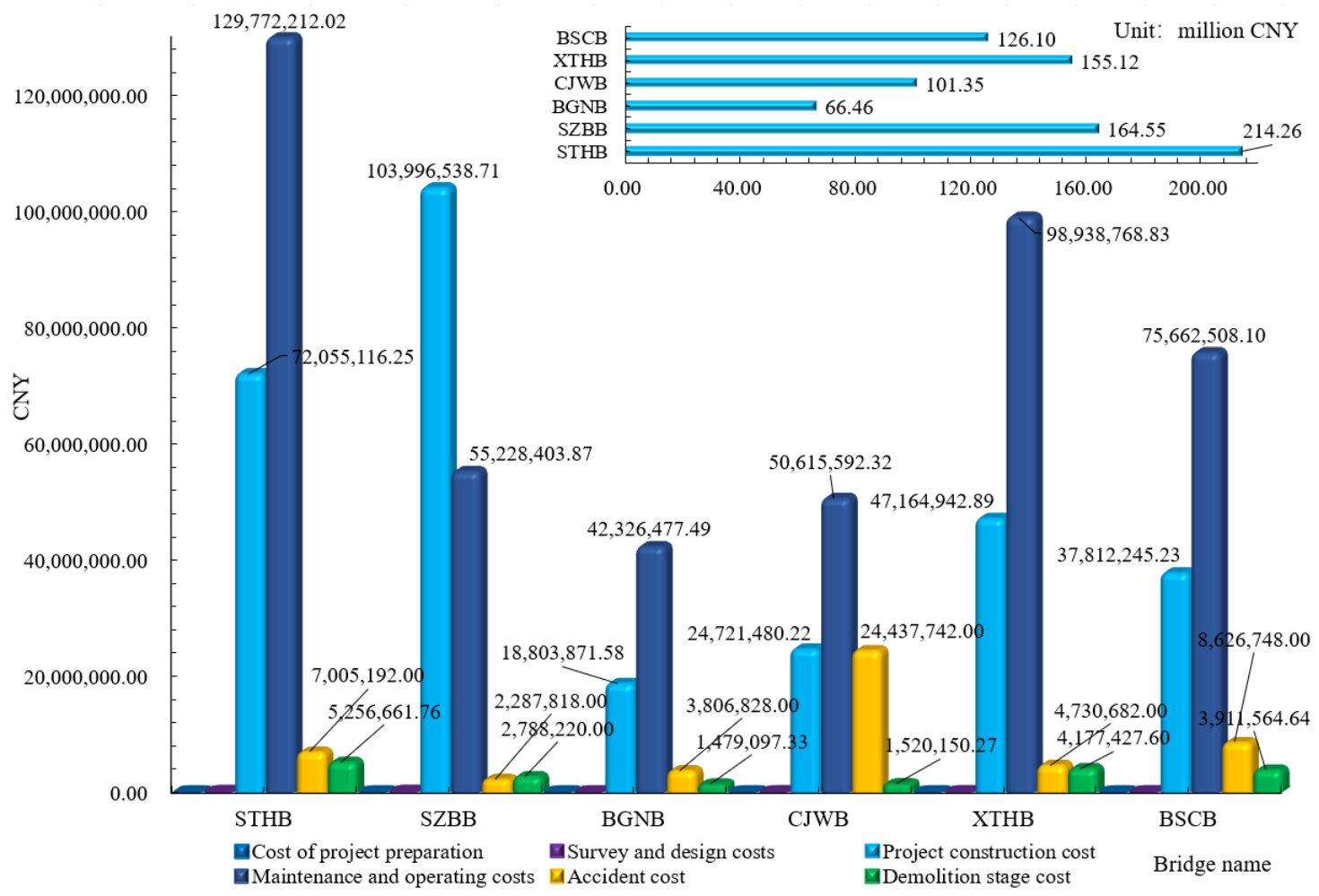

Figure 7. The cost diagram of six cable-stayed bridges at different stages.

\subsection{SILA}

SILA was conducted for the six cable-stayed bridges from four categories, including the population impact, community system, social resources and economic development. Five impact factors were selected according to the classification.

Table 9 shows some of the SILA values for the six bridges. For each cable-stayed bridge, corruption $>$ sanitation coverage $>$ fatal accidents $>$ international migrant workers $>$ youth illiteracy.

Table 9. Statistical table of five social environmental impact data for 6 cable-stayed bridges. Unit: med risk hours.

\begin{tabular}{cccccc}
\hline Bridge Name & Fatal Accidents & $\begin{array}{c}\text { International } \\
\text { Migrant Workers }\end{array}$ & Youth Illiteracy & Corruption & $\begin{array}{c}\text { Sanitation } \\
\text { Coverage }\end{array}$ \\
\hline STHB & $55,792,892.84$ & $31,765,165.76$ & $28,624,476.33$ & $118,864,998.3$ & $88,496,114.86$ \\
SZBB & $47,282,293.11$ & $26,919,734.79$ & $24,258,123.41$ & $1,007,33434$ & $74,996,993.87$ \\
BGNB & $6,502,779.89$ & $3,702,297.38$ & $3,336,243.37$ & $13,853,967.44$ & $10,314,409.72$ \\
CJWB & $9,202,951.4$ & $5,239,614.97$ & $4,721,563.11$ & $19,606,597.66$ & $14,597,297.3$ \\
XTHB & $28,358,724.3$ & $16,145,776.5$ & $14,549,409.27$ & $60,417,367.61$ & $44,981,301.3$ \\
BSCB & $14,063,615.15$ & $8,006,988.77$ & $7,215,320.78$ & $29,962,088.48$ & $22,307,058.1$ \\
\hline
\end{tabular}

As shown in Figure 8, the values of five impact factors in each stage of the six cablestayed bridges are ranked as follows:

Numbers ${ }_{\text {Construction and installation stage }}>$

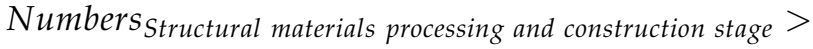

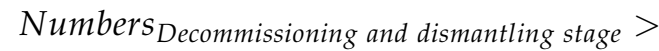

Numbers Design stage $>$ Numbers Maintenance and operation stage. 
(a) STHB Sanitation coverage

(a) STHB Corruption $34,391,175,57$ (a) STHB Fatal accidents

$70,000,000.00$ $60,000,000.00$ $50,000,000.00$ $40,000,000.00$ $30,000,000,00$ $45,854,900,77,0000000000$

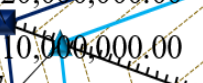

$21,236,488.28$
$8,315,317.71$ $15,049,142.97$

$0.00 \mathrm{~T}=1286,857.23$ $14,275,481,40$

$10,706,611.08$

$45,630,013.23$ (a) STHB International migrant workers (a) STHB Youth

\section{illiteracy}

$\rightarrow-$ Structural materials processing and construction stage

- Maintenance and operation stage

$\neg$-Decommissioning and dismantling stage

(b) SZBB Fatal accidents

(b) SZBB Sanitation coverage

$$
\begin{aligned}
& 60,000,000.00 \\
& 50,000,000.00 \\
& 40,000,000.00 \\
& 30,000,000.00
\end{aligned}
$$

(b) SZBB International migrant workers

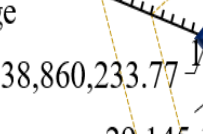

\section{(b) SZBB Corruption}

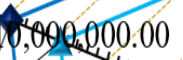

$9,565,169.77$

$12,753,559.69$

$-12,097,911.78$

$9,073,4 \ldots$ $\rightarrow$ Design stage

$\neg$ Construction and installation stage

$₫$ Decommissioning and dismantling stage

Unit: Med risk hours

(b) SZBB Youth illiteracy 
(c) BGNB Sanitation coverage

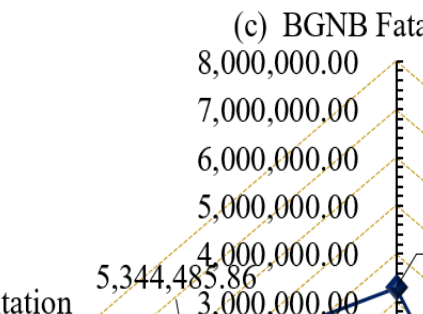

$8,000,000.00$

$7,000,000,00$

$6,000,000.00$

$4,000,000,00$

(n)

(c) BGNB Corruption

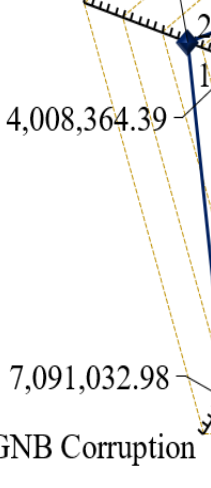

-Design stage

$\rightarrow$ Construction and installation stage

$₫$ Decommissioning and dismantling stage

Unit: Med risk hours

$\rightarrow-$ Structural materials processing and construction stage

$\rightarrow$ Maintenance and operation stage

(c) BGNB Youth illiteracy (c) BGNB International migrant workers (d) CJWB Sanitation 7,563,694,97 coverage

\section{(d) CJWB Corruption}

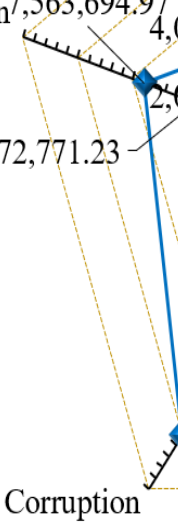

(d) CJWB Fatal accidents

$$
\begin{gathered}
12,000,000.00 \\
10,000,000.00 \\
8,000,000.00 \\
6,000,000.00
\end{gathered}
$$

$000,000.00$

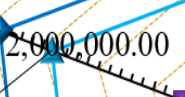

\section{0}

$3,502,925.90$

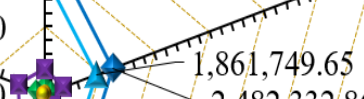

(d) CJWB International migrant workers $\neg$ Design stage

$\rightarrow-$ Construction and installation stage

- Decommissioning and dismantling stage

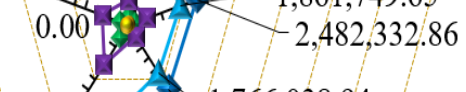

$1,766,038.94$

$2,354,718.58$

$7,526,600.12$

$10,035,466.83$

Unit: Med risk hours

(d) CJWB Youth illiteracy

$\rightarrow$-Structural materials processing and construction stage

- Maintenance and operation stage

Figure 8. Cont. 
(e) XTHB

Fatal accidents

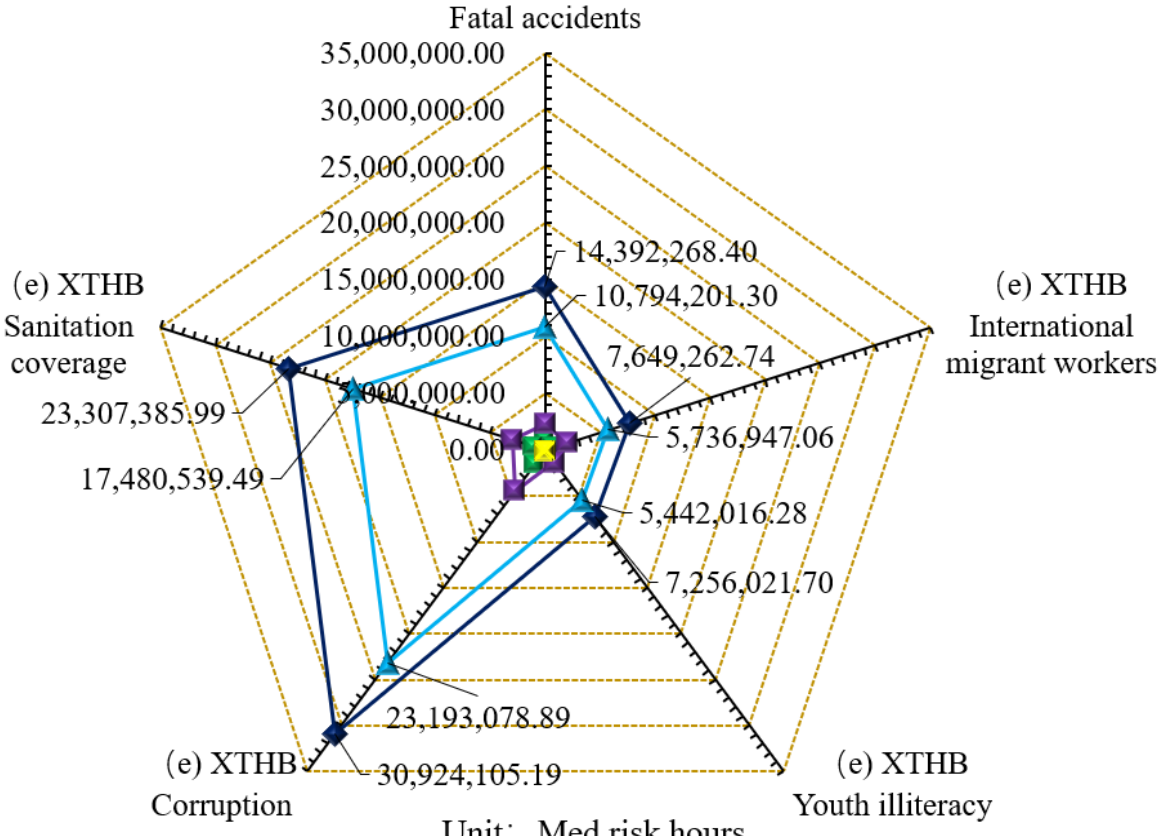

Corruption

Unit: Med risk hours

Design stage

Construction and installation stage

$\triangle$ Decommissioning and dismantling stage

-Structural materials processing and construction stage

a-Maintenance and operation stage

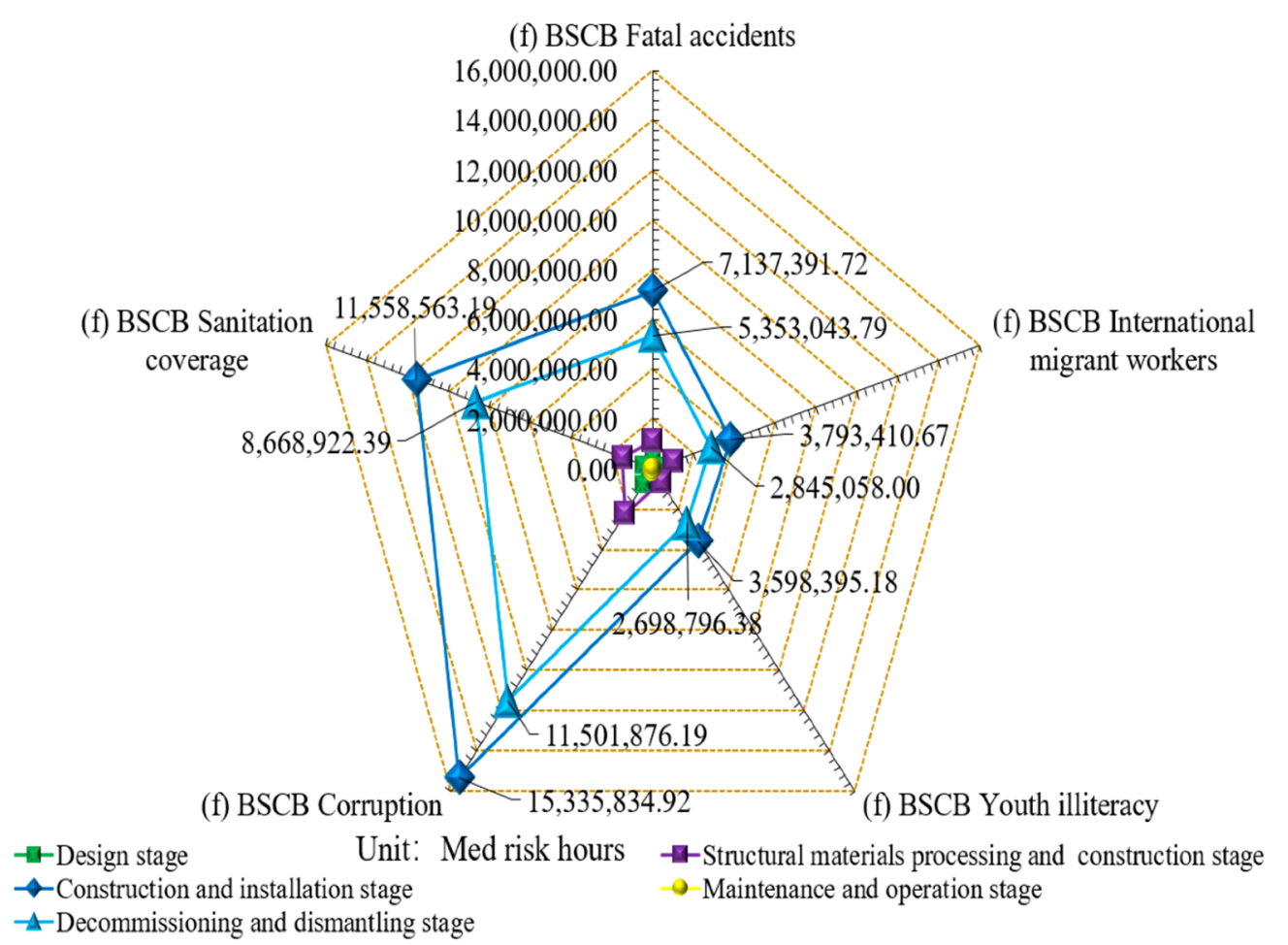

Figure 8. (a) The content in the first panel is the description of the five SILA factors of STHB; (b) The content in the second panel is the description of the five SILA factors of SZBB; (c) The content in the third panel is the description of the five SILA factors of BGNB; (d) The content in the fourth panel is the description of the five SILA factors of CJWB; (e) The content in the fifth panel is the description of the five SILA factors of XTHB; (f) The content in the sixth panel is the description of the five SILA factors of BSCB. 


\subsection{Deepen the Analysis}

\subsubsection{Economic Evaluation}

As shown in Figure 9, the bridges with the peak value of GDP in 10 years are SZBB and STHB (Government, n.d.); the bridges with the peak value of LCIA are STHB and XTHB; the bridges with the peak values of LCCA and SLCA are STHB and SZBB. The analysis concludes that the environmental pollution, production cost and social impact generated by infrastructure in developed regions increase accordingly. In particular, there is a complementary relationship between GDP and the emissions of environmentally polluting gases. The constant emission load of environmental pollution gases under GDP growth signifies that the current energy technologies must be replaced with renewable energy resources, and/or more energy-efficient production technologies must be adopted [95].

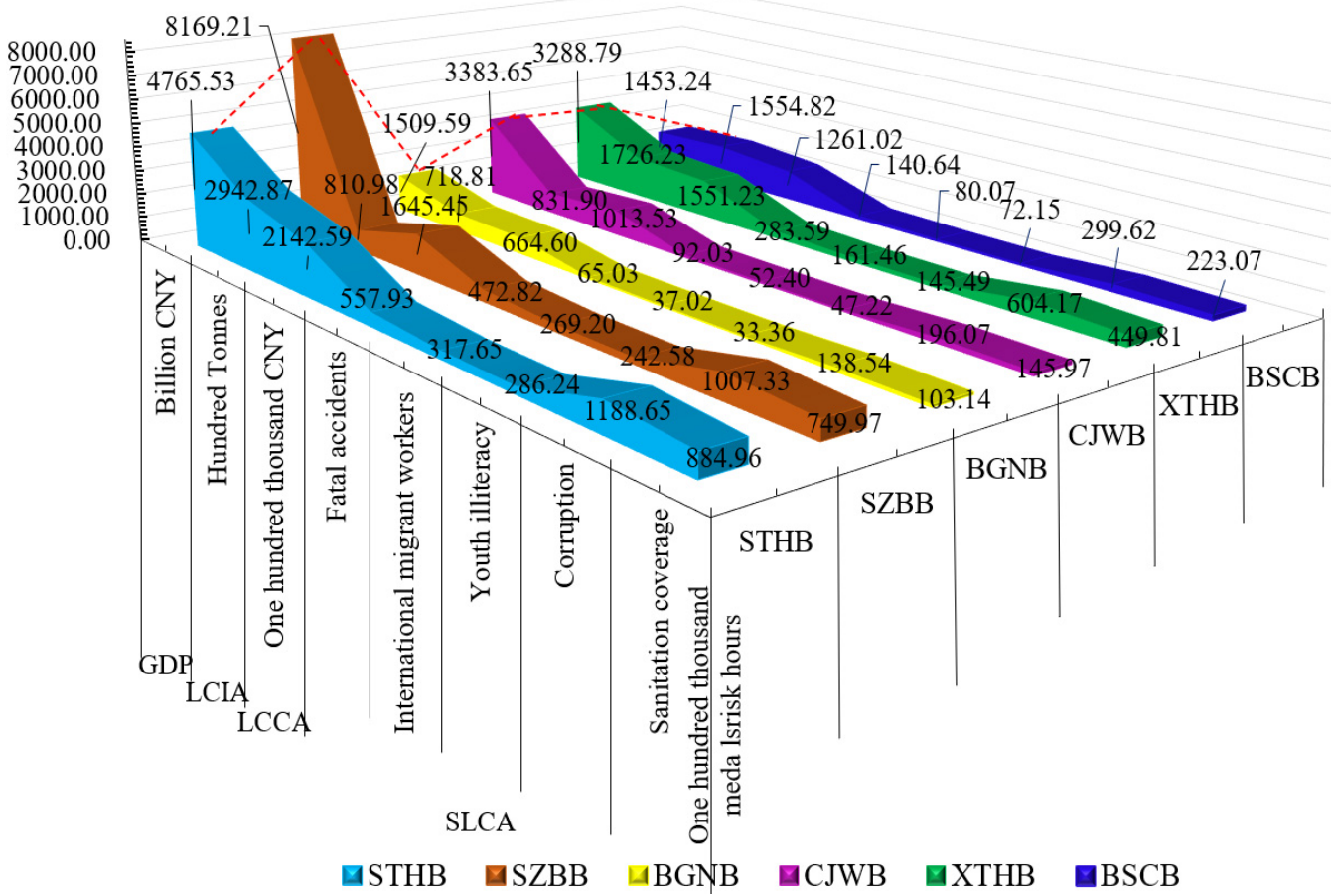

Figure 9. Schematic diagram of gross domestic product (GDP) [96], LCIA, LCCA, and SILA data in the area where the six cable-stayed bridges are located.

\subsubsection{Modelling and Discussion}

Definition of Markov chain: assuming that $X_{1}, X_{2}, \cdots \cdots X_{n}$ is the discrete sequence of random influence variables, abbreviated as $\left\{X_{n}\right\}$, the state space of the entire $\left\{X_{n}\right\}$ is denoted as $\mathrm{E}=\left\{\mathrm{x}_{1}, \mathrm{x}_{2}, \cdots \cdots \mathrm{x}_{\mathrm{n}}\right\}$; if any impact factor is subject to $\mathrm{x}_{\mathrm{i} 1} \mathrm{x}_{\mathrm{i} 2}, \cdots \cdots \mathrm{x}_{\mathrm{in}} \mathrm{E}$, then $\mathrm{P}\left(\mathrm{X}_{\mathrm{n}+1}\right)=\left(\mathrm{x}_{\mathrm{i}_{\mathrm{n}+1}} \mid \mathrm{X}_{1}=\mathrm{x}_{\mathrm{i}_{1}}, \cdots \cdots \mathrm{X}_{\mathrm{n}}=\mathrm{x}_{\mathrm{i}_{\mathrm{n}}}\right)$.

The impact matrix is established based on the definition,

$$
\mathrm{K}_{\mathrm{h}}=\left\{\begin{array}{cccc}
\mathrm{x}_{11}\left(\mathrm{~h}_{1}\right) & \mathrm{x}_{12}\left(\mathrm{~h}_{1}\right) \cdots \cdots & \mathrm{x}_{1 \mathrm{~m}}\left(\mathrm{~h}_{1}\right) & \mathrm{h}_{1}=\mathrm{GDP}_{\text {variables }} \\
\mathrm{x}_{21}\left(\mathrm{~h}_{2}\right) & \mathrm{x}_{22}\left(\mathrm{~h}_{2}\right) \cdots \cdots & \mathrm{x}_{2 \mathrm{~m}}\left(\mathrm{~h}_{2}\right) & \mathrm{h}_{2}=\mathrm{GWP}_{\text {variables }} \\
\vdots & \vdots & \vdots & \vdots \\
\vdots & \vdots & \vdots & \vdots \\
\mathrm{x}_{\mathrm{n} 1}\left(\mathrm{~h}_{\mathrm{k}}\right) & \mathrm{x}_{\mathrm{n} 2}\left(\mathrm{~h}_{\mathrm{k}}\right) \cdots \cdots & \mathrm{x}_{\mathrm{nm}}\left(\mathrm{h}_{\mathrm{k}}\right) & \mathrm{h}_{\mathrm{k}}=\mathrm{H}_{\text {variables }}
\end{array}\right.
$$

where $\mathrm{K}_{\mathrm{h}}=$ conclusion of the infrastructure's comprehensive impact assessment.

According to Equation (13), 


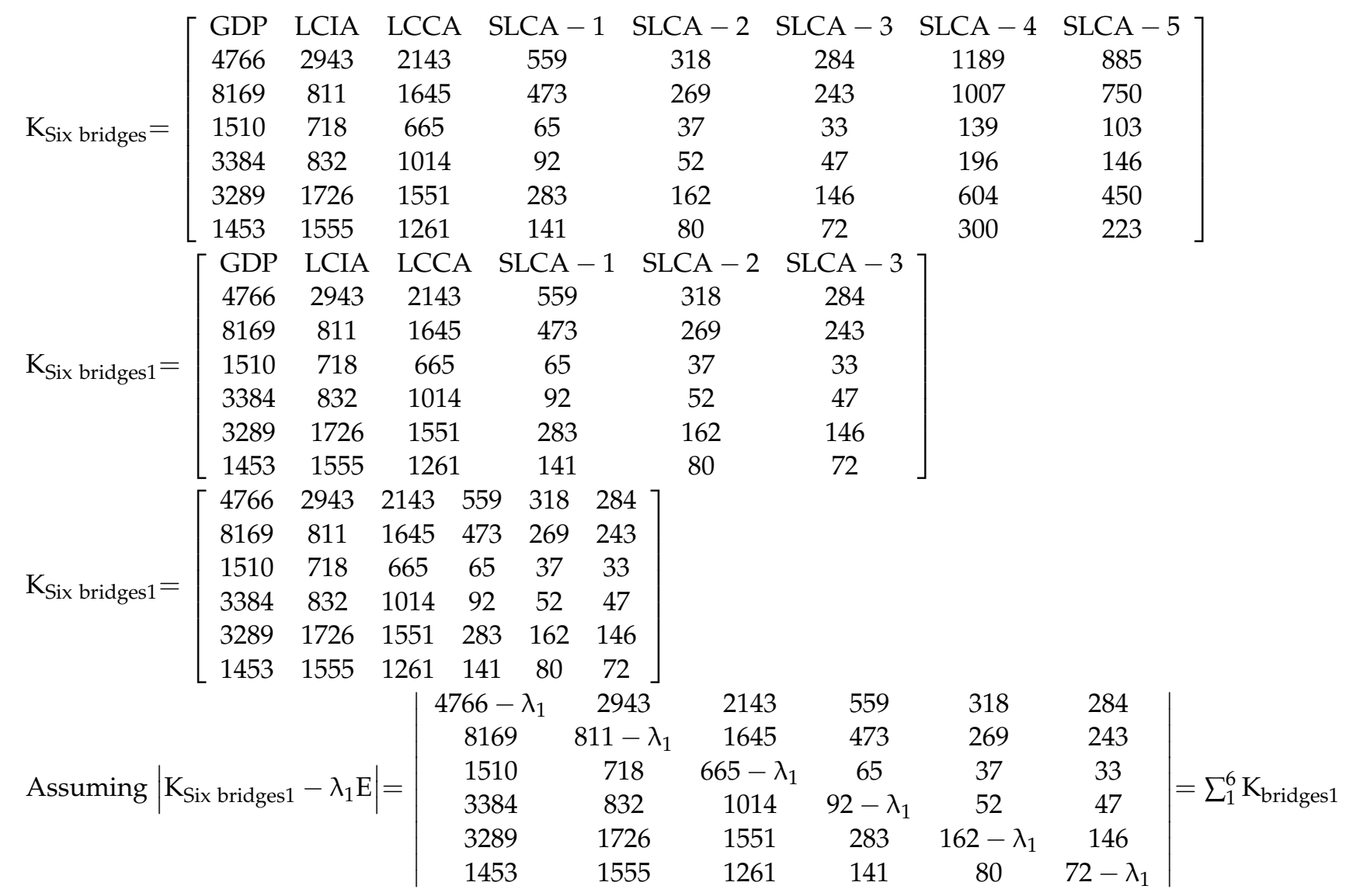

If the diagonal method is used, then $(14)=\left(4766-\lambda_{1}\right) \times\left(811-\lambda_{1}\right) \times(655-$ $\left.\lambda_{1}\right) \times\left(92-\lambda_{1}\right) \times\left(162-\lambda_{1}\right) \times\left(72-\lambda_{1}\right)-433287870784 \lambda_{1}-5454599392867510=0$, $\lambda_{1}=\sum_{1}^{7}(12588+4766+811+665+92+162+72) / 7=2736.7 \approx 2737$.

$$
\mathrm{K}_{\text {Six bridges } 2}=\left[\begin{array}{cccccc}
4766 & 2943 & 2143 & 559 & 1189 & 885 \\
8169 & 811 & 1645 & 473 & 1007 & 750 \\
1510 & 718 & 665 & 65 & 139 & 103 \\
3384 & 832 & 1014 & 92 & 196 & 146 \\
3289 & 1726 & 1551 & 283 & 604 & 450 \\
1453 & 1555 & 1261 & 141 & 300 & 223
\end{array}\right] \quad\left[\begin{array}{cccccc}
4766-\lambda_{2} & 2943 & 2143 & 559 & 1189 & 885 \\
8169 & 811-\lambda_{2} & 1645 & 473 & 1007 & 750 \\
1510 & 718 & 665-\lambda_{2} & 65 & 139 & 103 \\
3384 & 832 & 1014 & 92-\lambda_{2} & 196 & 146 \\
3289 & 1726 & 1551 & 283 & 604-\lambda_{2} & 450 \\
1453 & 1555 & 1261 & 141 & 300 & 223 \lambda_{2}
\end{array}\right]=\sum_{1}^{6} \mathrm{~K}_{\text {bridges2 }}
$$

If the diagonal method is used, then (15) $\left(4766-\lambda_{2}\right) \times\left(811-\lambda_{2}\right) \times\left(665-\lambda_{2}\right) \times$ $\left(92-\lambda_{2}\right) \times\left(604-\lambda_{2}\right) \times 223 \lambda_{2}-147825193568210000 \lambda_{2}-1046549405522410=0, \lambda_{2}=$ $\sum_{1}^{7}(82565+4766+811+665+92+604+223) / 7=12818$.

Based on Equations (14) and (15), we can conclude that the most reasonable impact range is $2737<\mathrm{K}_{\text {Six bridges }}<12818$.

According to Figure 10, five-point positions are located in the reasonable comprehensive evaluation range. The five points are Point (2) and (5) of STHB, Point (1) of SZBB, Point (3) of CJWB, and Point (4) of XTHB. 


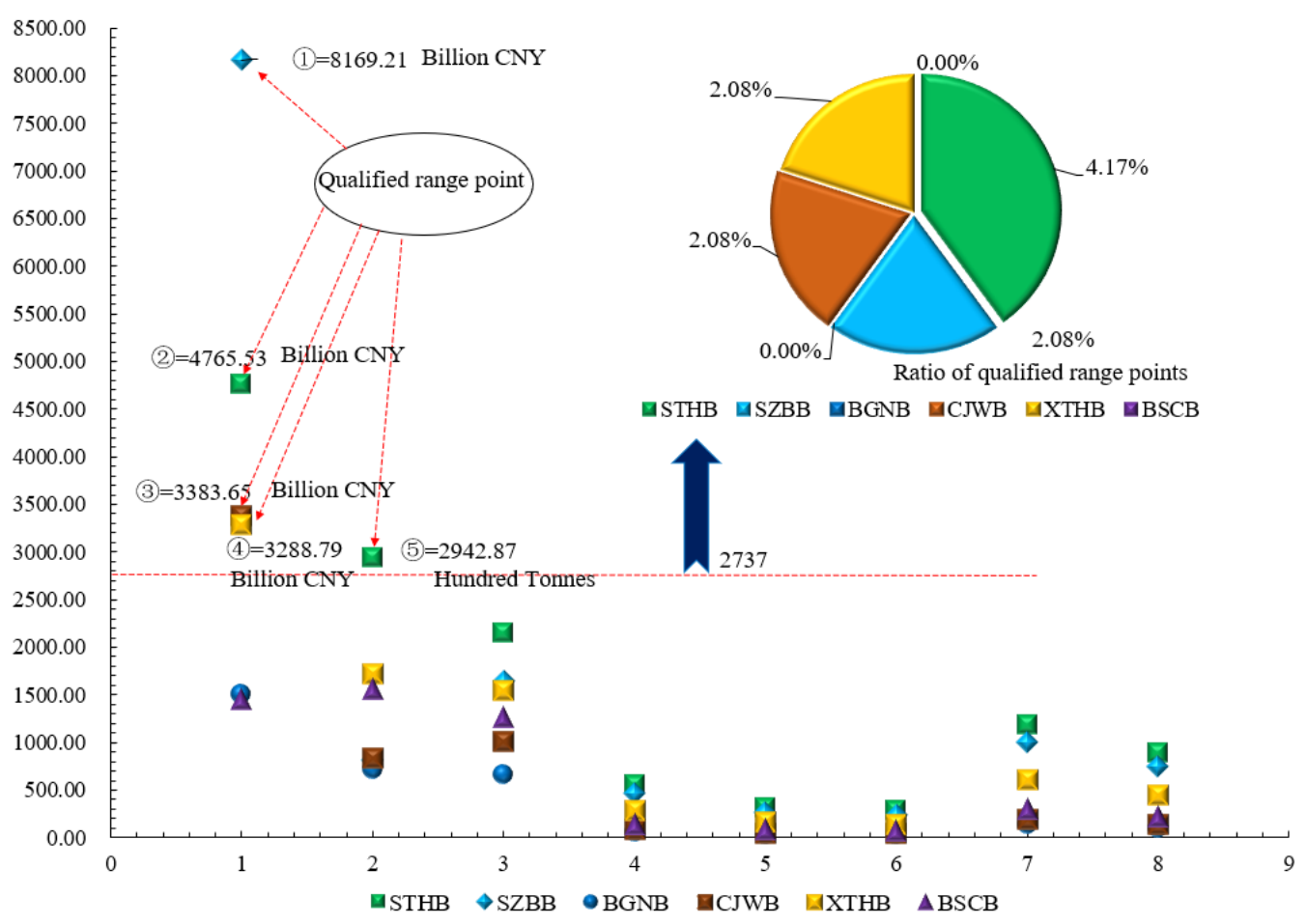

Figure 10. Schematic diagram of discrete points for comprehensive evaluation.

\section{Conclusions}

The manuscript proposes a comprehensive and effective sustainability assessment method and establishes an assessment framework and modelling theory for complex structural bridges (cable-stayed bridges) in terms of environment, economy, and social impact. Through the comprehensive evaluation of six highway cable-stayed bridges in five provinces of China in the whole life cycle (from cradle to grave), the conclusion is drawn. GWP is the main source of environmental pollution in LCIA, accounting for more than $92 \%$ of the emissions of each bridge, which are concentrated in the maintenance stage. In LCCA, the proportion of maintenance stage cost is $49-64 \%$. In SILA, the corruption value has the greatest influence, accounting for $36 \%$ of the total amount. The SZBB steel structure bridge is special: GWP accounts for 50\% in the LCIA material stage and $63.2 \%$ in the LCCA construction stage.

In view of the high pollution and high cost in the maintenance stage, the conclusion shows that it is closely related to the design standard and service life of the materials. It is found that the difference in LCIA between Europe and China is 33 73-fold, which is due to the difference in the replacement period between the main girder and stay cable of 80 years and 50 years/cycle. More interestingly, the LCIA value of SZBB in Europe is higher than that in China by 10,824.7 tonnes, because the maintenance period of steel structure differs by 15 years/cycle. The differences in the above conclusions are closely related to regional population density, vehicle ownership and traffic frequency, which is one of the research directions in the future.

Finally, to obtain the relationship between GDP and sustainable impact, the comprehensive evaluation coefficient of the influence matrix is established by using discrete mathematics for multi factor decision-making, and the reasonable range of 2737 12,818 (The theoretical judgment standard of innovation) between China's five major economic regional bridges and regional GDP is analysed.

This study aims to propose a complete method for assessing the sustainability of bridges. This article provides important knowledge for preliminary decisions in the construction of bridges as well as how to mitigate the loads of the three pillars. The limitation of the study is that there is no questionnaire survey in the social impact assessment, and it is 
impossible to compare and analyse whether there is a big difference between the conclusion and the actual impact. Future research directions need to strengthen the resilience analysis of evaluating the impact of the construction industry on society, and the mutual promotion and optimization of the GDP influencing factors and sustainable development.

Author Contributions: Investigation, Z.Z. and J.A.; methodology, Z.Z., J.A., and V.Y.; supervision, J.A. and V.Y.; validation, Z.Z. and V.Y.; writing—original draft, Z.Z.; writing-review and editing, J.A. and V.Y. All authors have read and agreed to the published version of the manuscript.

Funding: This research was funded by the Spanish Ministry of Economy and Competitiveness, along with FEDER (Fondo Europeo de Desarrollo Regional), project grant number: BIA2017-85098-R.

Conflicts of Interest: The authors declare no potential conflicts of interest with respect to the research, authorship, and/or publication of this article.

\section{References}

1. ISO 14044:2006/AMD 1:2017. Environmental Management-Life Cycle Assessment-Requirements and Guidelines. ISO. 2006. Available online: https:/ / www.iso.org/standard/72357.html (accessed on 20 November 2020).

2. Wuni, Y.; Shen, G.Q.P.; Osei-Kyei, R. Scientometric review of global research trends on green buildings in construction journals from 1992 to 2018. Energy Build. 2019, 190, 69-85. [CrossRef]

3. United Nations. World Population in 2050. Available online: https://www.un.org/development/desa/en/news/population/ world-population-prospects-2017.html (accessed on 20 November 2020).

4. Huisingh, D.; Zhang, Z.; Moore, J.C.; Qiao, Q.; Li, Q. Recent advances in carbon emissions reduction: Policies, technologies, monitoring, assessment and modeling. J. Clean. Prod. 2015, 103, 1-12. [CrossRef]

5. Zhang, X. Toward a regenerative sustainability paradigm for the built environment: From vision to reality. J. Clean. Prod. 2014, 65, 3-6. [CrossRef]

6. IPCC. Summary for Policymakers, Climate Change 2014: Mitigation of Climate Change. 2014. Available online: https://www. buildup.eu/en/practices / publications/ipcc-2014-climate-change-2014-mitigation-climate-change-contribution-working (accessed on 20 November 2020).

7. Dong, Y.H.; Ng, S.T. A social life cycle assessment model for building construction in Hong Kong. Int. J. Life Cycle Assess. 2015, 20, 1166-1180. [CrossRef]

8. Hellweg, S.; Canals, L.M.I. Emerging approaches, challenges and opportunities in life cycle assessment. Science 2014, 344, 1109-1113. [CrossRef]

9. Hansen, J.; Sato, M.; Kharecha, P.; Beerling, D.; Berner, R.; Masson-Delmotte, V.; Pagani, M.; Raymo, M.; Royer, D.L.; Zachos, J.C. Target Atmospheric CO: Where should Humanity Aim? Open Atmos. Sci. J. 2008, 2, 217-231. [CrossRef]

10. World Meteorological Organization. WMO Statement on the State of the Global Climate in 2016. 2017. Available online: https:/ /library.wmo.int/doc_num.php?explnum_id=3414 (accessed on 20 November 2020).

11. Muntean, M.; Guizzardi, D.; Schaaf, E.; Crippa, M.; Solazzo, E.; Olivier, J.G.J.; Vignati, E. Fossil CO 2 Emissions of All World Countries: 2018 Report; EU Science Hub, European Commission, Joint Research Centre: Ispra (VA), Italy, 2018 ; ISBN 9789279972409. [CrossRef]

12. Lin, B.; Liu, H. $\mathrm{CO}_{2}$ emissions of China's commercial and residential buildings: Evidence and reduction policy. Build. Environ. 2015, 92, 418-431. [CrossRef]

13. Kim, T.H.; Tae, S.H. Proposal of environmental impact assessment method for concrete in South Korea: An application in LCA (life cycle assessment). Int. J. Environ. Res. Public Health 2016, 13, 1074. [CrossRef]

14. Hildenbrand, J.; Michael Srocka, A.C. OpenLCA 1.10. 2020. Available online: http:/ /www.openlca.org/openlca/ (accessed on 23 November 2020).

15. ISO,14044:2006/AMD 2:2020, Environmental Management-Life Cycle Assessment-Requirements and Guidelines. ISO. 2006. Available online: https:/ / www.iso.org/standard/76122.html (accessed on 23 November 2020).

16. Navarro, I.J.; Yepes, V.; Martí, J.V.; González-Vidosa, F. Life cycle impact assessment of corrosion preventive designs applied to prestressed concrete bridge decks. J. Clean. Prod. 2018, 196, 698-713. [CrossRef]

17. O'Born, R. Life cycle assessment of large scale timber bridges: A case study from the world's longest timber bridge design in Norway. Transp. Res. Part. D Transport. Environ. 2018, 59, 301-312. [CrossRef]

18. Milani, C.J.; Kripka, M. Evaluation of short span bridge projects with a focus on sustainability. Struct. Infrastruct. Eng. 2020, 16, 367-380. [CrossRef]

19. Trunzo, G.; Moretti, L.; D'Andrea, A. Life cycle analysis of road construction and use. Sustainability 2019, 11, 377. [CrossRef]

20. Li, H.; Deng, Q.; Zhang, J.; Xia, B.; Skitmore, M. Assessing the life cycle $\mathrm{CO}_{2}$ emissions of reinforced concrete structures: Four cases from China. J. Clean. Prod. 2019, 210, 1496-1506. [CrossRef]

21. Frangopol, D.M.; Dong, Y.; Sabatino, S. Bridge life-cycle performance and cost: Analysis, prediction, optimisation and decisionmaking. Struct. Infrastruct. Eng. 2017, 13, 1239-1257. [CrossRef] 
22. Goh, K.C.; Goh, H.H.; Chong, H.-Y. Integration Model of Fuzzy AHP and Life-Cycle Cost Analysis for Evaluating Highway Infrastructure Investments. J. Infrastruct. Syst. 2019, 25, 04018045. [CrossRef]

23. Heidari, M.R.; Heravi, G.; Esmaeeli, A.N. Integrating life-cycle assessment and life-cycle cost analysis to select sustainable pavement: A probabilistic model using managerial flexibilities. J. Clean. Prod. 2020, 254. [CrossRef]

24. Wang, Z.; Yang, D.Y.; Frangopol, D.M.; Jin, W. Inclusion of environmental impacts in life-cycle cost analysis of bridge structures. Sustain. Resilient Infrastruct. 2020, 5, 252-267. [CrossRef]

25. Cadenazzi, T.; Dotelli, G.; Rossini, M.; Nolan, S.; Nanni, A. Life-Cycle Cost and Life-Cycle Assessment Analysis at the Design Stage of a Fiber-Reinforced Polymer-Reinforced Concrete Bridge in Florida. Adv. Civ. Eng. Mater. 2019, 8, 20180113. [CrossRef]

26. ESMS. Social Impact Assessment (SIA). 2016. Available online: https://www.iucn.org/sites/dev/files/iucn_esms_sia_guidance_ note.pdf (accessed on 23 November 2020).

27. Zhang, A.; Zhong, R.Y.; Farooque, M.; Kang, K.; Venkatesh, V.G. Blockchain-based life cycle assessment: An implementation framework and system architecture. Resour. Conserv. Recycl. 2020, 152, 104512. [CrossRef]

28. Parent, J.; Cucuzzella, C.; Revéret, J.P. Impact assessment in SLCA: Sorting the sLCIA methods according to their outcomes. Int. J. Life Cycle Assess. 2010, 15, 164-171. [CrossRef]

29. Vanclay, F. Reflections on Social Impact Assessment in the 21st century. Impact Assess. Proj. Apprais. 2020, 38, 126-131. [CrossRef]

30. Zamarrón-Mieza, I.; Yepes, V.; Moreno-Jiménez, J.M. A systematic review of application of multi-criteria decision analysis for aging-dam management. J. Clean. Prod. 2017, 147, 217-230. [CrossRef]

31. Parsons, R. Forces for change in social impact assessment. Impact Assess. Proj. Apprais. 2020, 38, 278-286. [CrossRef]

32. Vanclay, F. Statistical Analysis on the Number of Traffic Accidents in China. Impact Assess. Proj. Apprais. 2003, 21, 3-4. [CrossRef]

33. Domínguez-Gómez, J.A. Four conceptual issues to consider in integrating social and environmental factors in risk and impact assessments. Environ. Impact Assess. Rev. 2016, 56, 113-119. [CrossRef]

34. Fischer, T.B.; Jha-Thakur, U.; Fawcett, P.; Clement, S.; Hayes, S.; Nowacki, J. Consideration of urban green space in impact assessments for health. Impact Assess. Proj. Apprais. 2018, 36, 32-44. [CrossRef]

35. Balasbaneh, A.T.; Marsono, A.K. Bin Applying multi-criteria decision-making on alternatives for earth-retaining walls: LCA, LCC, and S-LCA. Int. J. Life Cycle Assess. 2020, 25, 2140-2153. [CrossRef]

36. Balasbaneh, A.T.; Marsono, A.K.B.; Khaleghi, S.J. Sustainability choice of different hybrid timber structure for low medium cost single-story residential building: Environmental, economic and social assessment. J. Build. Eng. 2018, 20, 235-247. [CrossRef]

37. Penadés-Plà, V.; Martínez-Muñoz, D.; García-Segura, T.; Navarro, I.J.; Yepes, V. Environmental and Social Impact Assessment of Optimized Post-Tensioned Concrete Road Bridges. Sustainability 2020, 12, 4265. [CrossRef]

38. Ali, M.S.; Aslam, M.S.; Mirza, M.S. A sustainability assessment framework for bridges—A case study: Victoria and Champlain Bridges, Montreal. Struct. Infrastruct. Eng. 2016, 12, 1381-1394. [CrossRef]

39. Kloepffer, W. Life cycle sustainability assessment of products (with Comments by Helias A. Udo de Haes, p. 95). Int. J. Life Cycle Assess. 2008, 13, 89-95. [CrossRef]

40. $\mathrm{Hu}, \mathrm{M}$. Building impact assessment-A combined life cycle assessment and multi-criteria decision analysis framework. Resour. Conserv. Recycl. 2019, 150, 104410. [CrossRef]

41. Association, E.; Ecoinvent Datebase. Ecoinvent. 2019. Available online: https://www.ecoinvent.org/database/database.html (accessed on 23 November 2020).

42. Bedec Datebase. The Regional Catalan Government. 2010. Available online: https://en.itec.cat/database/ (accessed on 23 November 2020).

43. Psilca Greendatebase. Available online: https://psilca.net/ (accessed on 23 November 2020).

44. Ortiz, O.; Castells, F.; Sonnemann, G. Sustainability in the construction industry: A review of recent developments based on LCA. Constr. Build. Mater. 2009, 23, 28-39. [CrossRef]

45. Asdrubali, F.; Baldassarri, C.; Fthenakis, V. Life cycle analysis in the construction sector: Guiding the optimization of conventional Italian buildings. Energy Build. 2013, 64, 73-89. [CrossRef]

46. European Union. International Reference Life Cycle Data System (ILCD) Handbook; Springer Science + Business Media B.V.: Berlin, Germany, 2011; p. 2011933605. Available online: https://link.springer.com/chapter/10.1007/978-94-007-1899-9_11 (accessed on 23 November 2020).

47. Ramesh, T.; Prakash, R.; Shukla, K.K. Life cycle energy analysis of buildings: An overview. Energy Build. 2010, 42, 1592-1600. [CrossRef]

48. Cabeza, L.F.; Rincón, L.; Vilariño, V.; Pérez, G.; Castell, A. Life cycle assessment (LCA) and life cycle energy analysis (LCEA) of buildings and the building sector: A review. Renew. Sustain. Energy Rev. 2014, 29, 394-416. [CrossRef]

49. Chau, C.K.; Leung, T.M.; Ng, W.Y. A review on life cycle assessment, life cycle energy assessment and life cycle carbon emissions assessment on buildings. Appl. Energy 2015, 143, 395-413. [CrossRef]

50. Baker, L. Of embodied emissions and inequality: Rethinking energy consumption. Energy Res. Soc. Sci. 2018, 36, 52-60. [CrossRef]

51. Chen, L.; Pelton, R.E.O.; Smith, T.M. Comparative life cycle assessment of fossil and bio-based polyethylene terephthalate (PET) bottles. J. Clean. Prod. 2016, 137, 667-676. [CrossRef]

52. Walker, S.; Rothman, R. Life cycle assessment of bio-based and fossil-based plastic: A review. J. Clean. Prod. 2020, $261,121158$. [CrossRef] 
53. Recipe. 2008. Available online: https://www.researchgate.net/publication/230770853_Recipe_2008 (accessed on 30 November 2020).

54. New Version Recipe. New Version ReCiPe 2016 to Determine Environmental Impact I RIVM. 2016. Available online: https: //www.rivm.nl/en/news/new-version-recipe-2016-to-determine-environmental-impact (accessed on 30 November 2020).

55. Penadés-Plà, V.; Martí, J.V.; García-Segura, T.; Yepes, V. Life-cycle assessment: A comparison between two optimal post-tensioned concrete box-girder road bridges. Sustainability 2017, 1864, 1864. [CrossRef]

56. Zhou, Z.; Alcalá, J.; Yepes, V. Bridge Carbon Emissions and Driving Factors Based on a Life-Cycle Assessment Case Study: Cable-Stayed Bridge over Hun He River in Liaoning, China. Int. J. Environ. Res. Public Health 2020, 17, 5953. [CrossRef]

57. SimaPro. 2020. Available online: https://simapro.com/about/ (accessed on 23 November 2020).

58. Lee, K.M.; Cho, H.N.; Cha, C.J. Life-cycle cost-effective optimum design of steel bridges considering environmental stressors Eng. Struct. 2006, 28, 1252-1265. [CrossRef]

59. Navarro, I.J.; Penadés-Plà, V.; Martínez-Muñoz, D.; Rempling, R.; Yepes, V. Life cycle sustainability assessment for multi-criteria decision making in bridge design: A review. J. Civil Eng. Manag. 2020, 26, 690-704. [CrossRef]

60. García-Segura, T.; Penadés-Plà, V.; Yepes, V. Sustainable bridge design by metamodel-assisted multi-objective optimization and decision-making under uncertainty. J. Clean. Prod. 2018, 202, 904-915. [CrossRef]

61. Jang, B.; Mohammadi, J. Impact of fatigue damage from overloads on bridge life-cycle cost analysis. Bridge Struct. 2019, 15, 181-186. [CrossRef]

62. Matos, J.; Solgaard, A.; Santos, C.; Silva, M.S.; Linneberg, P.; Strauss, A.; Casas, J.; Caprani, C.; Akiyama, M. Life cycle cost, as a tool for decision making on concrete infrastructures. In Proceedings of the High-Tech Concrete: Where Technology and Engineering Meet, Maastricht, The Netherlands, 12-14 June 2017; Springer International Publishing: Berlin, Germany, 2017; pp. 1832-1839. [CrossRef]

63. Edited by the Policy Research Office, National Development and Reform Commission, 2011. National Development and Re-Form Commission Notified to Reduce Fees for Some Construction Projects. Available online: https://www.ndrc.gov.cn/xwdt/xwfb/ 201103/t20110323_956782.html (accessed on 23 November 2020).

64. Edited by the Ministry of Construction, National Development and Reform Commission, 2002. Engineering Survey and Design Charging Standards. Available online: https://wenku.baidu.com/view/3fa74a62effdc8d376eeaeaad1f34693daef1088.html (accessed on 23 November 2020).

65. Stewart, M.G. Analysis of Climate Change Impacts on the Deterioration of Concrete Infrastructure-Part. 1: Mechanisms, Practices... Analysis of Climate Change Impacts on the Deterioration of Concrete Infrastructure Part. 1: Mechanisms, Practices, Modelling and Sim; CSIRO: Canberra, Australia, 2016; ISBN 9780643103658; pp. 1-88. Available online: https://apo.org.au/sites/default/files/ resource-files /2011-02/apo-nid25469_5.pdf (accessed on 23 November 2020).

66. Rossi, B.; Marquart, S.; Rossi, G. Comparative life cycle cost assessment of painted and hot-dip galvanized bridges. J. Environ. Manag. 2017, 197, 41-49. [CrossRef]

67. Ministry of Communications of China, 2004; Code for Maintenance of Highway Bridge and Culvers. Available online: http: / / www.chhca.org.cn/web_html/001/HYDT03.asp (accessed on 23 November 2020).

68. Wang, H.; Schandl, H.; Wang, X.; Ma, F.; Yue, Q.; Wang, G.; Wang, Y.; Wei, Y.; Zhang, Z.; Zheng, R. Measuring progress of China's circular economy. Resour. Conserv. Recycl. 2020, 163, 105070. [CrossRef]

69. National Bureau of Statistics-2019. Available online: http://www.stats.gov.cn/tjsj/ndsj/ (accessed on 23 November 2020). (In Chinese)

70. Wang, D.; Liu, Q.; Ma, L.; Zhang, Y.; Cong, H. Road traffic accident severity analysis: A census-based study in China. J. Saf. Res. 2019, 70, 135-147. [CrossRef]

71. Van der Vlegel, M.; Haagsma, J.A.; de Munter, L.; de Jongh, M.A.C.; Polinder, S. Health Care and Productivity Costs of Non-Fatal Traffic Injuries: A Comparison of Road User Types. Int. J. Environ. Res. Public Health 2020, 17, 2217. [CrossRef]

72. Al-Rukaibi, F.; AlKheder, S.; AlOtaibi, N.; Almutairi, M. Traffic crashes cost estimation in Kuwait. Int. J. Crashworthiness 2020, 25, 203-212. [CrossRef]

73. Jiménez, J.R.; Ayuso, J.; Agrela, F.; López, M.; Galvín, A.P. Utilisation of unbound recycled aggregates from selected CDW in unpaved rural roads. Resour. Conserv. Recycl. 2012, 58, 88-97. [CrossRef]

74. Tavira, J.; Jiménez, J.R.; Ayuso, J.; Sierra, M.J.; Ledesma, E.F. Functional and structural parameters of a paved road section constructed with mixed recycled aggregates from non-selected construction and demolition waste with excavation soil. Constr. Build. Mater. 2018, 164, 57-69. [CrossRef]

75. Sangiorgi, C.; Lantieri, C.; Dondi, G. Construction and demolition waste recycling: An application for road construction. Int. J. Pavement Eng. 2015, 16, 530-537. [CrossRef]

76. Prenzel, P.V.; Vanclay, F. How social impact assessment can contribute to conflict management. Environ. Impact Assess. Rev. 2014, 45, 30-37. [CrossRef]

77. Vanclay, F. International principles for social impact assessment. Impact Assess. Proj. Apprais. 2003, 21, 5-12. [CrossRef]

78. Esteves, A.M.; Franks, D.; Vanclay, F. Social impact assessment: The state of the art. Impact Assess. Proj. Apprais. 2012, 30, 34-42. [CrossRef]

79. Sierra, L.A.; Pellicer, E.; Yepes, V. Method for estimating the social sustainability of infrastructure projects. Environ. Impact Assess. Rev. 2017, 65, 41-53. [CrossRef] 
80. Navarro, I.J.; Yepes, V.; Martí, J.V. Social life cycle assessment of concrete bridge decks exposed to aggressive environments. Environ. Impact Assess. Rev. 2018, 72, 50-63. [CrossRef]

81. Shab-Home. 2020. Available online: http://www.socialhotspot.org/ (accessed on 23 November 2020).

82. Ciroth, A.; Eisfeldt, F. PSILCA-A Product Social Impact Life Cycle Assessment Database Database Version 1.0. 2016. Available online: https://www.openlca.org/wp-content/uploads/2016/08/PSILCA_documentation_v1.1.pdf (accessed on 23 November 2020).

83. Wiki. Geographical Division of China-Wikiwand. Wiki. 2020. Available online: https://www.wikiwand.com/en/Geography_ of_China (accessed on 23 November 2020).

84. List of New Cities in China-Wikiwand. 2020. Available online: https://m.sohu.com/n/486287408/ (accessed on 23 November 2020).

85. Baishan City People's Government. 2020. Available online: http://www.cbs.gov.cn/sq/sthj/201805/t20180519_323816.html. (accessed on 23 November 2020).

86. Dargay, J.; Gately, D.; Sommer, M. The saturation is 807 cars per 1000 people. Energy J. 2007, 28, 143-170. [CrossRef]

87. Wu, T.; Zhang, M.; Ou, X. Analysis of Future Vehicle Energy Demand in China Based on a Gompertz Function Method and Computable General Equilibrium Model. Energies 2014, 7, 7454-7482. [CrossRef]

88. Huzhou Statistical Yearbook-2019. Available online: http://tjj.huzhou.gov.cn/hustats/html/tjnj2019/05.html (accessed on 20 November 2020).

89. Shi, Y.; Guo, S.; Sun, P. The role of infrastructure in China's regional economic growth. J. Asian Econ. 2017, 49, 26-41. [CrossRef]

90. Announced by the Ministry of Transport of the People's Republic of China, M. of T. of the P.R. of Highway Engineering Construction Project Estimate Budget Preparation Method (JTG 3830-2018). Ministry of Transport of the People's Republic of China. 2019. Available online: http://xxgk.mot.gov.cn/2020/jigou/glj/202006/t20200623_3313130.html (accessed on 24 November 2020). (In Chinese)

91. Department of Science and Technology, Ministry of Transport. Announced by the Ministry of Transport of the People's Republic of China, M. of T. of the P.R. of. Highway Engineering Industry Standard. China Communications Press Co.,Ltd. 2018. Available online: http:/ / www.mot.gov.cn/ (accessed on 24 November 2020).

92. Vanclay, F.; Franks, D.M. International Association for Impact Assessment Purpose and Intended Readership. 2015, pp. 1-74. Available online: https:/ / www.socialimpactassessment.com/documents/IAIA\%202015\%20Social\%20Impact $\% 20$ Assessment $\%$ 20guidance\%20document.pdf (accessed on 24 November 2020).

93. Appiah-Opoku, S. Land access and resettlement: A guide to best practice, by Gerry Reddy, Eddie Smyth, and Michael Steyn. Impact Assess. Proj. Apprais. 2015, 33, 290. [CrossRef]

94. Fomento, T. Virtual de Publicaciones del M. de. 2010. Code on Structural Concrete (EHE-08) Articles and Annexes. Available online: http:/ / asidac.es/asidac-en/wp-content/uploads/2016/07/EHE-ENG.pdf (accessed on 26 November 2020).

95. Suzuki, S.; Nijkamp, P. An evaluation of energy-environment-economic efficiency for EU, APEC and ASEAN countries: Design of a Target-Oriented DFM model with fixed factors in Data Envelopment Analysis. Energy Policy 2016, 88, 100-112. [CrossRef]

96. Government, C. Data of GDP. Available online: http:/ / www.gov.cn/shuju/index.htm (accessed on 24 November 2020). 